\title{
Distribution and habitat ecology of the sorediate species of Menegazzia (Parmeliaceae, lichenized Ascomycota) in Chile
}

\author{
Distribución y ecología de las especies sorediosas de Menegazzia (Parmeliaceae, \\ Ascomycota liquenizado) en Chile
}

JARLE W. BJERKE ${ }^{1,3}$, ARVE ELVEBAKK ${ }^{1} \&$ WANDA QUILHOT ${ }^{2}$

\begin{abstract}
${ }^{1}$ Department of Biology, Faculty of Science, University of Troms $\varnothing$, N-9037 Troms $\varnothing$, Norway
${ }^{2}$ Escuela de Farmacia, Facultad de Medicina, Universidad de Valparaíso, Casilla 5001, Chile ${ }^{3}$ Corresponding author: jarleb@ibg.uit.no
\end{abstract}

\begin{abstract}
The taxonomy and ecology of the sorediate species of Menegazzia from the southernmost regions of Chile and Argentina and the South Atlantic Islands was recently published, only with sporadic reports from the more northern regions. In the present work the distribution patterns and habitat ecology of the sorediate species are discussed, with emphasis on the area north of $48^{\circ} \mathrm{S}$. Eleven species are treated. Menegazzia subpertusa, an epiphyte of sclerophyll scrubs, is recorded from South America for the first time (Chile and Argentina). Menegazzia neozelandica has a disjunct distribution in Chile, with occurrences in Fray Jorge (Fourth Region of Chile) and on Islas Juan Fernández, and along the coast south of latitude $38^{\circ} \mathrm{S}$. Menegazzia kawesqarica and M. tenuis are most common in the southernmost part of Chile, but are also found at high altitudes at lower latitudes. Additional treated species are M. chrysogaster, M. fumarprotocetrarica, $M$. globulifera, $M$. magellanica, $M$. norsorediata, $M$. sanguinascens and $M$. wandae. Several of the sorediate species are early colonisers of newly developed substrates. They show variable occurrences along light and humidity gradients. Distribution maps and a revised key are presented.
\end{abstract}

Key words: lichens, Chile, Menegazzia, biogeography, climatic gradients.

\section{RESUMEN}

Recientemente se han publicado datos sobre la taxonomía y ecología de las especies sorediosas de Menegazzia representadas en las regiones más australes de Chile y Argentina e islas del Atlántico Sur, además de registros esporádicos en zonas ubicadas más al norte en Chile. En este trabajo se discuten los patrones de distribución y la ecología del hábitat de 11 especies sorediosas, con especial enfásis en aquellas que se desarrollan al norte de los $48^{\circ} \mathrm{S}$. Menegazzia subpertusa, un epífito de arbustos esclerófilos, se registra por primera vez en América (Chile y Argentina). Menegazzia neozelandica tiene una distribución discontinua en Chile; ha sido recolectada en Fray Jorge (Cuarta Región de Chile), Islas Juan Fernández y en regiones costeras al sur de los $38^{\circ} \mathrm{S}$. Menegazzia kawesqarica y M. tenuis son más frecuentes en las zonas más australes de Chile; también se han encontrado en hábitats de altura y bajas latitudes. Se incluyen, además, $M$. chrysogaster, $M$. fumarprotocetrarica, M. globulifera, M. magellanica, M. norsorediata, $M$. sanguinascens y $M$. wandae. Varias especies sorediosas crecen como pioneras en sustratos jóvenes. Los patrones de distribución a lo largo de gradientes de humedad y de luz son variables. Se presentan mapas de distribución y clave de las especies.

Palabras clave: liquenes, Chile, Menegazzia, biogeografía, gradientes climáticos.

\section{INTRODUCTION}

The genus Menegazzia A. Massal. constitutes a prominent part of the lichen mycobiota in the forests of southern South America (Santesson 1942). The checklist of Chilean lichens lists 14 species (Galloway \& Quilhot 1999). Subsequently, the sorediate species from the southernmost regions of Chile and Argentina were revised by Bjerke \& Elvebakk (2001), including descriptions of two new species. An additional new species known between latitudes $38^{\circ} 30^{\prime}$ and $46^{\circ} 40^{\prime} \mathrm{S}$ in Chile was recently described (Bjerke 2001), and a list of species of Menegazzia known from Laguna San Rafael National Park was published (Quilhot et al. 2002a, 2002b). Calvelo \& Adler (1994), Adler \& Calvelo (1996), and most recently Bernasconi et al. (2002), treated the species of Menegazzia in Argentina. After our revisions from southernmost Chile, further field studies and analyses of herbarium material were undertaken. Through these studies, a more complete understanding of the distribution and habitat ecology of the sorediate species of 
Menegazzia were obtained, and the new results are presented here. Special emphasis is given to the distribution of species in the regions not treated by Bjerke \& Elvebakk (2001), viz. all regions north of the Magellanic region (Duodécima Región de Magallanes y de la Antártica Chilena). Some reports on the sorediate species of Menegazzia from regions Four to Eleven exist (e.g., Räsänen 1932, Redon et al. 1975, Quilhot et al. 1975, and literature reports cited in detail in results and discussion). These reports are revised here. Distribution maps and a revised key to the sorediate species are presented.

\section{MATERIAL AND METHODS}

Field studies and collecting trips were performed in all regions of Chile, including Islas Juan Fernández. No material of Menegazzia was found north of latitude $30^{\circ} \mathrm{S}$. Laboratory studies were mainly done on material collected by the present authors, especially on the numerous specimens collected by the third author during the last 30 years and deposited in the Herbarium at Universidad de Valparaíso (UV). Most specimens collected by the first and second authors are housed in TROM. Additional material, including specimens of extra-American species for comparisons and many type specimens, were seen in or obtained from the following herbaria: B, BG, BM, GZU, H, HIP, HO, MSC, O, S and UPS. Specimens examined by Bjerke \& Elvebakk (2001) are included on the maps here, and in the total number of examined specimens, but not referred to in any more detail. For Quilhot's specimens, the collection numbers are equivalent to the herbarium's accession numbers. The brief descriptions of all treated species are based on descriptions and illustrations in Bjerke (2001) and Bjerke \& Elvebakk (2001), and new data. Other sources for morphological traits are cited when available. Thin-layer chromatography of acetone extracts was performed using standardised procedures (Culberson 1972, White \& James 1985). Only commonly-occurring secondary substances are mentioned below. For less common substances, see Bjerke \& Elvebakk (2001). Nomenclature follows Galloway \& Quilhot (1999) for lichens, except for Coccotrema coccophorum (Schmitt et al. 2001), and Marticorena \& Quezada (1986) for plants.

\section{Bioclimatic regions and vegetation zones in Chile}

Forested and lowland parts of Chile are divided into four major bioclimatic zones by Amigo \&
Ramírez (1998, called 'belts' or 'regions'), viz. tropical, Mediterranean, temperate, and boreal. The southernmost zone has also been termed 'antiboreal' (e.g., Tuhkanen 1992, Elvebakk \& Moberg 2002), and here the use of this term is advocated. Several divisions of Chile into vegetation zones are published (e.g., Schmithüsen 1956, Grau 1992, 1995, Arroyo et al. 1993, Donoso 1995). A modified bioclimatic division of Chile, based on the above-mentioned literature sources and on own observations, is given here. For the antiboreal zone, a simplified nomenclature adopted from Elvebakk \& Moberg (2002) is used. The zones are as follows: (1) tropical zone, north of $25^{\circ} \mathrm{S}$, see boundary line shown by Amigo \& Ramírez (1998); (2) Mediterranean zone, north of $37^{\circ} \mathrm{S}$, see boundary line shown by Amigo \& Ramírez (1998). No species of Menegazzia occur within the tropical and Mediterranean belts, and further zonal divisions are therefore not given here; (3) temperate zone, between latitudes $37^{\circ}$ and $51^{\circ} \mathrm{S}$, but with relict, disjunct enclaves at Talinay-Fray Jorge at $30^{\circ} \mathrm{S} ;(4)$ antiboreal zone, south of latitude $51^{\circ} \mathrm{S}$. See Elvebakk \& Moberg (2002) for an interpretation of the temperateantiboreal boundary.

The temperate zone is further divided into: (A) the warm-temperate lowland forest, dominated by thermophilous deciduous and evergreen angiosperm trees, such as Nothofagus obliqua, Persea lingue and Peumus boldus; (B) the Valdivian rainforest. Dominated by evergreen trees like Nothofagus dombeyi, N. alpina, $N$. nitida, Drimys winteri, Aextoxicon punctatum, Myrceugenia exsucca and Weinmannia trichosperma; (C) the north-Patagonian cool-temperate rainforest. Dominated by Nothofagus dombeyi and lacking a number of tree species found in the Valdivian rainforest; (D) the highaltitude mixed deciduous-coniferous forest. Dominated by Nothofagus dombeyi, N. pumilio and $N$. antarctica, and different gymnosperms such as Araucaria araucana, Austrocedrus chilensis, Fitzroya cupressoides, Podocarpus spp. and Saxegothaea conspicua are locally abundant; and (E) the east Patagonian steppe. Various zones dominated by Junellia tridens, Mulinum spinosum and Festuca gracillima, respectively, see Elvebakk \& Moberg (2002) for more details on the steppe zones.

The antiboreal zone was divided into: (A) the Magellanic moorland. A mosaic of blanket bogs of cushion plants/bryophytes and woodlands of Nothofagus betuloides, Embothrium coccineum and Pilgerodendron uviferum; (B) the antiboreal rainforest. Dominated by tall, evergreen forest of Nothofagus betuloides and Drimys winteri; (C) 
the antiboreal deciduous forest. Dominated by Nothofagus pumilio and N. antarctica; and (D) the antiboreal heathland. Dominated by Chiliotrichum diffusum and Empetrum rubrum.

The distribution of the sorediate species of Menegazzia is related to the bioclimatic zones and subzones in order to understand more about the species' ecological requirements.

\section{RESULTS AND DISCUSSION}

The species

Menegazzia chrysogaster Bjerke \& Elvebakk, Mycotaxon 78: 371 (2001).

Type: Chile, Ninth Region of Chile, Province of Malleco, Malalcahuello, 12 October 1987, W. Quilhot 2004 (S !, holotype; UV !, isotype).

Menegazzia chrysogaster is a South American endemic species that has convex white or yellowish soralia, wide, slightly convex and partly glossy lobes, and a characteristic ochre-yellow upper side of the internal cavity. The upper surface is greyish-green with small maculae, and often with slightly pruinose lobe tips. The margins of the lobes become black, especially towards the centre.

Chemistry: atranorin, stictic acid, cryptostictic acid, constictic acid and unidentified ochre-yellow pigments.

Variation: Menegazzia chrysogaster has a more variable morphology than first thought, thalli from more light-exposed microhabitats tend to be more greyish than the more common pale green thalli found in shadier habitats. The crater-like depressions found in one specimen from Argentina (Bjerke \& Elvebakk 2001) were not seen in specimens from Chile. The degree of maculation, pruinosity and blackening of margins is also variable. Lobes vary from contiguous towards apices and imbricate to contiguous with open spaces between lobes. Two collections from Isla Desolación made by P. Dusén in 1896 and published as M. sanguinascens by Santesson (1942) were discussed in context with $M$. chrysogaster by Bjerke \& Elvebakk (2001). More detailed morphological and chemical studies revealed that these collections include thalli of $M$. chrysogaster, $M$. norsorediata and $M$. sanguinascens.

Distribution: In Chile from latitude $36^{\circ} 50^{\prime} \mathrm{S}$ (Termas de Chillán, VIII Region of Chile) to $53^{\circ} 22^{\prime}$ S (Península Brunswick, XII Region of Chile) (Fig. 1). It is also known from Isla de los Estados in southern Argentina (Bjerke \& Elvebakk 2001). Most known localities are from forests surrounding the Andean cordillera, but a few localities closer to the Pacific Ocean are known, e.g., along Cordillera de La Costa.

Habitat ecology: Menegazzia chrysogaster is an epiphyte of trees and shrubs in low- to medium-light situations in Nothofagus forests from

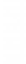

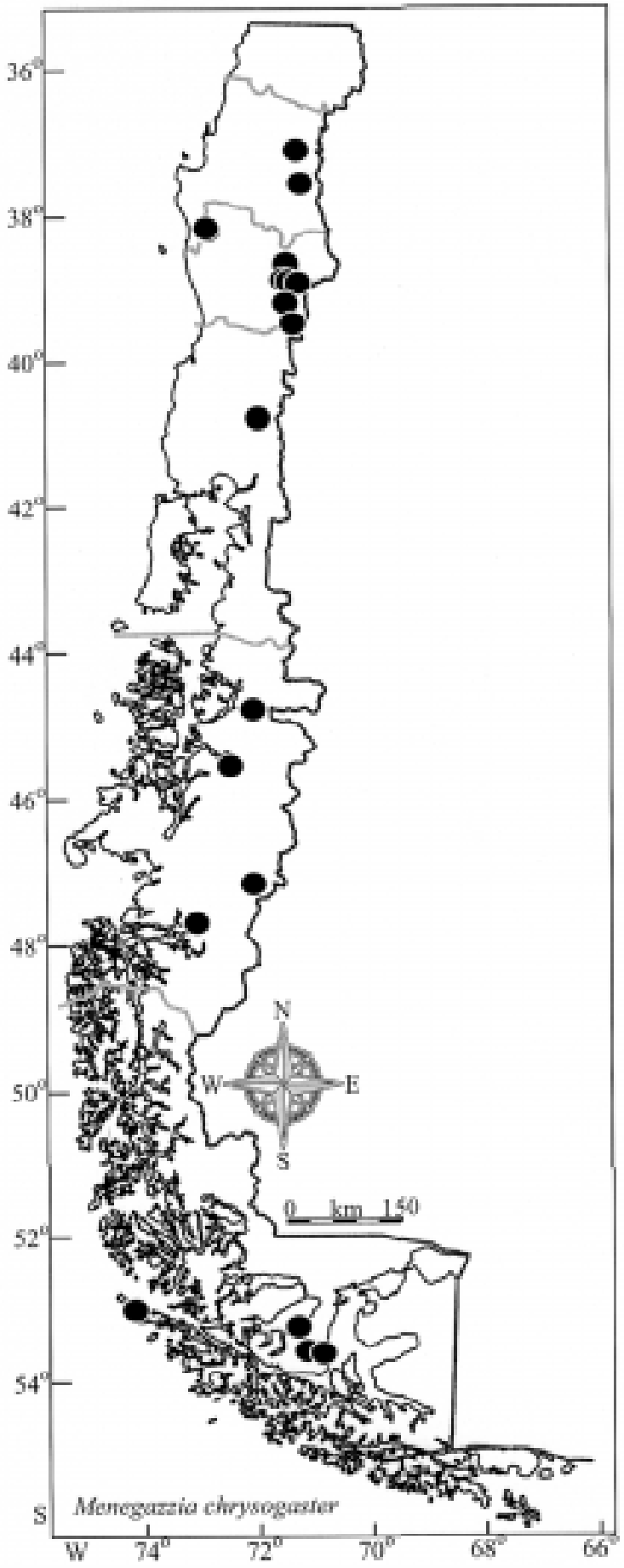

Fig. 1: Distribution of Menegazzia chrysogaster in Chile.

Distribución de Menegazzia chrysogaster en Chile. 
about $150 \mathrm{~m}$ in Nahuelbuta to $1,400 \mathrm{~m}$ close to the Argentinean border in the Ninth Region of Chile. It has an altitudinal range from sea level to $200 \mathrm{~m}$ in the southernmost part of its distribution range. It is most common and best-developed on the lower parts of the smooth-barked trunks of Nothofagus dombeyi, N. betuloides and N. pumilio. It is also known from Austrocedrus chilensis, Maytenus magellanica, Pseudopanax laetevirens, Berberis ilicifolia and Embothrium coccineum. Like most South American species of Menegazzia, it avoids the more rough-barked trunks of older trees, and of other phorophytes, where broadlobed species of Pseudocyphellaria, Nephroma and Sticta are predominant. On trunks, it forms large rosettes that effectively compete for space with other lichens and mosses. Under rather humid and low-light conditions, it associates with M. sanguinascens, M. albida, M. cincinnata, Hypogymnia subphysodes, Bunodophoron spp., Nephroma australe, Pseudocyphellaria glabra, Parmeliella sp., Psoroma leprolomum and $P$. pallidum. In more light-exposed situations, as in Tamango (Eleventh Region of Chile) and Conguillío (Ninth Region of Chile), it associates with Menegazzia kawesqarica, M. globulifera, M. cincinnata, M. norsorediata, Normandina pulchella, Tuckermannopsis chlorophylla, Coelopogon epiphorellus, Platismatia glauca, Pannoparmelia angustata, Protousnea spp. and Pseudocyphellaria hirsuta.

Selected specimens examined (total 45). Chile. Eighth Region, Province of Ñuble: Shangri-La, Termas de Chillán, May 1984, W. Quilhot 1854 (UV). Ninth Region of Chile, Province of Malleco: Malalcahuello, September 1968, J. Redon 01286 (UV 1840); Parque Nacional Nahuelbuta, 27 February 2001, J. W. Bjerke 915/01, 955/01 (TROM), 927/01 (UV). Ninth Region of Chile, Province of Cautín: Parque Nacional Conguillío, Río Captrén 19 December 1978, W. Quilhot 3062 (UV); ca. halfway between Melipeuco and Icalma, 28 November 2001, J. W. Bjerke 1361/01, 1367/01, 1369/01 (TROM); Parque Nacional Huerquehue, W. Quilhot 3061 (UV); Parque Nacional Villarica, 11 December 1983, W. Quilhot 3116 (UV). Tenth Region of Chile, Province of Osorno: Parque Nacional Puyehue, Antillanca, 16 December 1980, W. Quilhot 3114 (UV). Eleventh Region of Chile, Province of Aisén: Carretera Austral, November 1993, W. Quilhot 1809 (UV). Eleventh Region of Chile, Province of Capitán Prat: Lago Cochrane, 19 November 1993, W. Quilhot 1376 (UV). Twelfth Region of Chile, Province of Magallanes: Reserva Forestal Laguna Parrillar, 26 November 1999, A. Elvebakk 99:754 [erronously included under $M$. kawesqarica by Bjerke \& Elvebakk
(2001)] (TROM), Isla Desolación, Puerto Angosto, 16 April 1896, P. Dusén s.n. [admixed with M. norsorediata] (S L11547).

Menegazzia fumarprotocetrarica Calvelo \& Adler, Mycotaxon 59: 369 (1996).

Type: Argentina, Province of Río Negro, Bariloche, Llao Llao, 7 October 1993, S. Calvelo 37861 (BAFC, holotype).

Menegazzia fumarprotocetrarica is a South American endemic species that has soralia formed on 1-2 mm tall pustules, a greenish, glossy upper surface, and small perforations with flat or slightly elevated rims. Its major medullary constituent is fumarprotocetraric acid, which makes it chemically very distinct from other South American representatives. It is discussed in detail and illustrated in Adler \& Calvelo (1996) and in Bjerke \& Elvebakk (2001).

Chemistry: atranorin and fumarprotocetraric acid.

Variation: Menegazzia fumarprotocetrarica shows some variation in thallus size and morphology of soralia. The widest lobes are found in the specimens from the south (to $2.0 \mathrm{~mm}$ wide), whereas lobes from shadier habitats in the north are not wider than $1.1 \mathrm{~mm}$ wide. The southern populations are also duller and slightly more pruinose than in the north. The form and size of the sorediate pustules appears to depend upon the age of the soralia. In old pustules, few soredia are remaining, and an open duct to the cavity is evident, whereas younger pustules have welldefined convex, richly sorediate apices.

Distribution: Menegazzia fumarprotocetrarica is a rare species in Chile known from latitude 37²9' S (Nahuelbuta, Ninth Region of Chile) to $5^{\circ} 22^{\prime}$ S (Península Brunswick, Twelfth Region of Chile) (Fig. 2). It is also known from a few localities in Argentina (Adler \& Calvelo 1996, Bjerke \& Elvebakk 2001, Bernasconi et al. 2002).

Habitat ecology: Menegazzia fumarprotocetrarica is most common in fairly open, mixed Nothofagus-Araucaria forests along Cordillera de Nahuelbuta and the Andean Cordillera in the Ninth Region of Chile, where it grows on the hard bark of trunks and branches of Nothofagus alpina, N. dombeyi and Araucaria araucana. On the latter phorophyte, it finds a remarkable habitat between and underneath the needles. In the Ninth Region of Chile, it associates with Menegazzia globulifera, M. norsorediata, Hypogymnia subphysodes, Parmelia protosulcata, Pannoparmelia angustata, Protousnea spp. and Bryoria sp. The only known locality of $M$. fumarprotocetrarica in the Eleventh Region of Chile is from a shrubby vegetation dominated by 
Embothrium coccineum near the glacier in Laguna San Rafael. In the southernmost part of Chile and Argentina, it is known from Nothofagus antarctica swamp forests and $N$. betuloides forests (Bjerke \& Elvebakk 2001).

Selected specimens examined (total 14). Chile. Ninth Region of Chile, Province of Malleco: Malacahuello, 12 October 1983, W. Quilhot 3179 (UV); Parque Nacional Nahuelbuta, 8-10 October 1987, W. Quilhot 2022A, 3109 (UV); Parque Nacional Nahuelbuta, between Centro de Informaciones and Piedra del Águila, 27 February 2001, J. W. Bjerke 954/01, 960/01 (UV), 993/ 01 (TROM). Ninth Region of Chile, Province of Cautín: Parque Nacional Conguillío, Cabañas La Baita, 29 November 2001, J. W. Bjerke 1420B/01 (TROM); Parque Nacional Villarica, 11 December 1983, W. Quilhot 1817A (UV). Eleventh Region of Chile, Province of Aisén: Parque Nacional Laguna San Rafael, November 1997, W. Quilhot 1639 (UV).

Menegazzia globulifera R. Sant., Arkiv för Botanik 30A, 11: 25 (1942).

Type: Argentina, Tierra del Fuego, Puesto Millaldeo, north of Lago Fagnano, 16 January 1929, H. Roivainen s.n. (S, holotype).

Menegazzia globulifera is a pan-austral species having vesicular, helmet-shaped soralia, a yellow-green shining upper surface and usnic acid in the upper cortex. It is discussed in detail in Santesson (1942), Galloway (1985) and James \& Galloway (1992).

Chemistry: usnic acid and lecanoric acid.

Variation: Menegazzia globulifera has a rather constant morphology apart from shape of soralia and thallus colour. Older soralia tend to erode, with only the basal part of the vesicle remaining, whereas young, immature soralia are more or less convex. In shaded habitats, $M$. globulifera partly looses its yellow-green colour. Only trace amounts of usnic acid are detected in specimens from these habitats.

Distribution: in Chile from latitude $36^{\circ} 50^{\prime} \mathrm{S}$ (Termas de Chillán, Eighth Region of Chile) to $55^{\circ} 05^{\prime} \mathrm{S}$ (Isla Navarino, Twelfth Region of Chile) (Fig. 3). It is also known from Argentina (Santesson 1942, Calvelo \& Adler 1994), Australia (James \& Galloway 1992) and New Zealand (Galloway 1985).

Habitat ecology: Menegazzia globulifera is an epiphyte of trees and shrubs in light-exposed, relatively dry vegetation. It is occasionally also saxicolous. It is known from the following phorophytes: Nothofagus pumilio, N. dombeyi, $N$. betuloides, N. antarctica, N. alpina, Araucaria araucana, Chiliotrichum diffusum, Berberis linearifolia, B. empetrifolia, B. ilicifolia and Embothrium coccineum. In regions Eight to Ten, it is a high-altitude species with altitudinal range from ca. 500 to $1,800 \mathrm{~m}$, only with scattered occurrences at lower altitudes. It is probably more

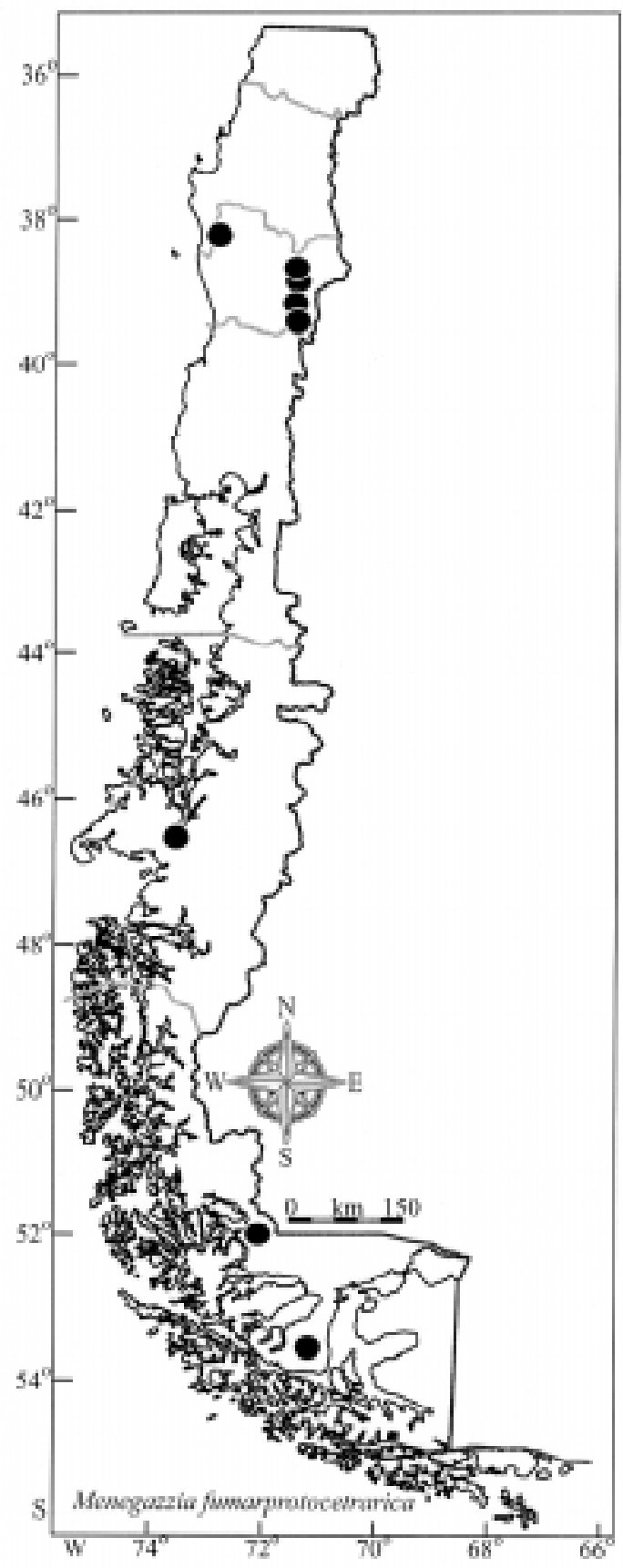

Fig. 2: Distribution of Menegazzia fumarprotocetrarica in Chile.

Distribución de Menegazzia fumarprotocetrarica en Chile. 
common in the Tenth Region of Chile than the map (Fig. 3) indicates, but few collections from higher altitudes than $700 \mathrm{~m}$ were available from that region. It appears to be most frequent in relatively dry and open forests dominated by Nothofagus pumilio south of latitude $45^{\circ} \mathrm{S}$. It is often found in association with other usnic acidproducing species, such as Protousnea spp., Usnea spp., Hypotrachyna sinuosa and Pannoparmelia angustata.

Selected specimens examined (total 53). Chile. Eighth Region, Province of Nuble: Termas de Chillán, 19 January 1998, W. Quilhot 1367 (UV). Ninth Region of Chile, Province of Malleco: Malalcahuello, 12 December 1987, W. Quilhot 1338 (UV); Parque Nacional Nahuelbuta, 8 October 1987, W. Quilhot 1330 (UV). Ninth Region of Chile, Province of Cautín: Parque Nacional Conguillío, Río Captrén, 12 February 1978, W. Quilhot 1366 (UV); ca. halfway between Melipeuco and Icalma, 28 November 2001, J. W. Bjerke 1370/01 (TROM); Icalma, 3 December 1985, W. Quilhot 1364 (UV). Eleventh Region of Chile, Province of Aisén: Parque Nacional Laguna San Rafael, November 1997, W. Quilhot 1635 (UV). Eleventh Region of Chile, Province of Capitan Prat: Cochrane, 17 November 1984, W. Quilhot 1339 (UV).

Menegazzia kawesqarica Bjerke \& Elvebakk, Mycotaxon 78: 376 (2001).

Type: Chile, Twelfth Region, Province of Magallanes, Morro Chico, in the central depression of the volcanic rock outcrop, $52^{\circ} 03^{\prime} \mathrm{S}, 71^{\circ} 28^{\prime}$ $\mathrm{W}$, on a vertical south-facing cliff surface, $22 \mathrm{~m}$ alt, 28 November 1999, A. Elvebakk 99:875 (S !, holotype; HO !, TROM !, isotypes).

Menegazzia kawesqarica is a southern South American endemic species characterised by a greyish, patchily blackened and corrugate upper surface, by large, convex, partly confluent soralia, and by wide, convex, prominently maculate lobes.

Chemistry: atranorin, stictic acid, cryptostictic acid, menegazziaic acid and constictic acid.

Variation: the northern populations of $M$. kawesqarica differ slightly from the southern populations by having less corrugate and less pruinose lobes, and by having soralia that are not so confluent. Some specimens of $M$. kawesqarica produce apothecia without producing mature asci and ascospores (Bjerke \& Elvebakk 2001). One large apothecium was found in a specimen from the Eleventh Region of Chile (W. Quilhot 3005), but asci were not found.

Distribution: in Chile from latitude $37^{\circ} 49^{\prime} \mathrm{S}$ (Nahuelbuta, Eleventh Region of Chile) to $53^{\circ} 22^{\text {' }}$ S (Península Brunswick, Twelfth Region of Chile)
(Fig. 4). It is still not recorded from Argentina. These are the first records from Chile north of latitude $47^{\circ} \mathrm{S}$.

Habitat ecology: in the Ninth Region of Chile it is an epiphyte of large trees in high-altitude

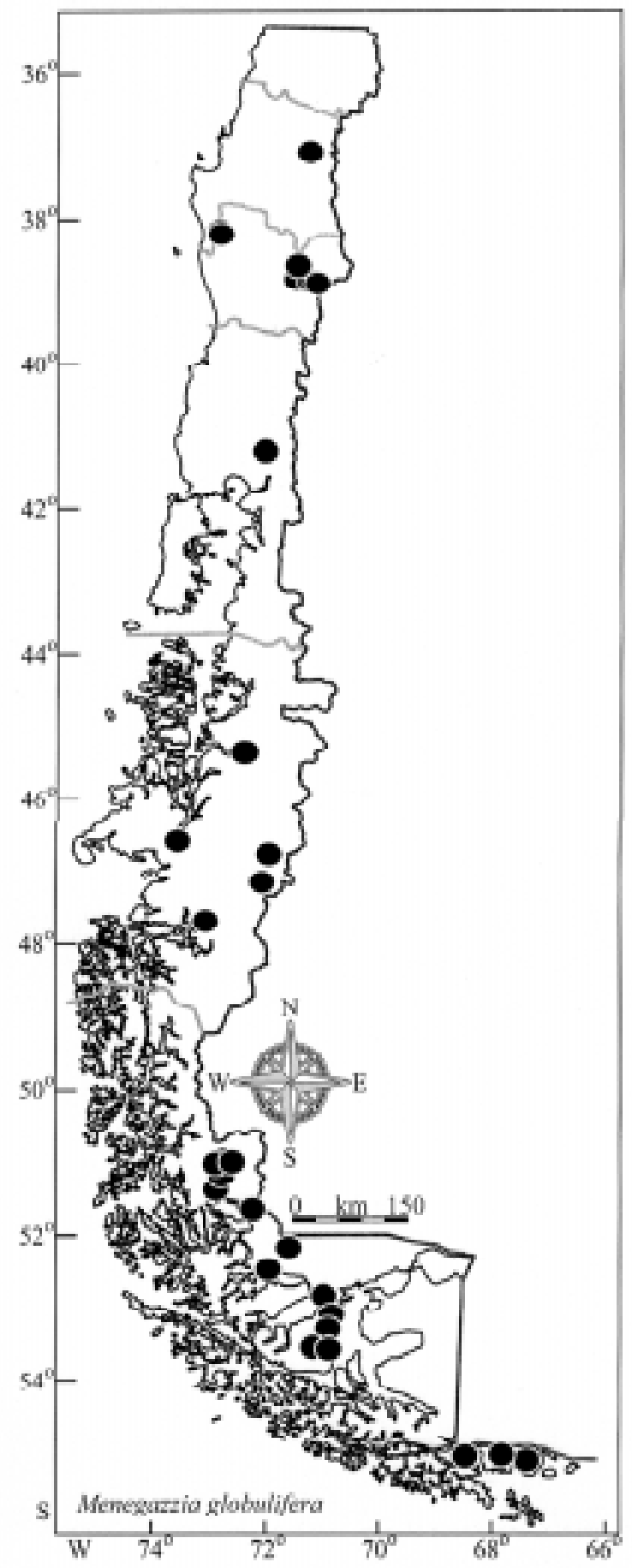

Fig. 3: Distribution of Menegazzia globulifera in Chile.

Distribución de Menegazzia globulifera en Chile. 
forests from $800 \mathrm{~m}$ to at least $1,400 \mathrm{~m}$. It is most common on trunks of Nothofagus dombeyi and $N$. alpina, but is also known from trunks of Podocarpus andinus, Araucaria araucana and Austrocedrus chilensis. It prefers trunks of relatively isolated trees with fairly high direct solar radiation, but is also occasionally found on more shaded trunks. In Tamango (Eleventh Region of Chile), it grows on trunks of Nothofagus pumilio in open semi-dry vegetation. In the Twelfth Region, $M$. kawesqarica is known from trunks of $N$. pumilio, N. antarctica and Maytenus magellanica, and is also common on shaded rock outcrops (Bjerke \& Elvebakk 2001). It is often found in association with Menegazzia globulifera, $M$. magellanica, M. chrysogaster (especially in Tamango), Protousnea spp., Tuckermannopsis chlorophylla, Coelopogon epiphorellus, Psoroma soccatum, Psoroma pallidum and Hypotrachyna sinuosa.

Selected specimens examined (total 29). Chile. Ninth Region of Chile, Province of Malleco: Malalcahuello, 12 October 1987, W. Quilhot 2005 (TROM \& UV), 2007B (UV), 2007C (TROM); Ninth Region of Chile, Parque Nacional Nahuelbuta, $0.3 \mathrm{~km}$ east of Piedra del Águila, 27 February 2001, J. W. Bjerke 992B/01 (TROM). Ninth Region of Chile, Province of Cautín: Parque Nacional Conguillío, 13 December 1983, W. Quilhot s.n., 1315 (UV), 12 May 2000, W. Quilhot 3057 (UV); Parque Nacional Conguillío, Cabañas La Baita, 29 November 2001, J. W. Bjerke 1437/ 01, 1441/01 \& D. J. Galloway s.n. (TROM), ca. halfway between Melipeuco and Icalma, 28 November 2001, J. W. Bjerke 1371/01 (TROM); Parque Nacional Huerquehue, W. Quilhot 1837A (UV). Eleventh Region of Chile, Province of Capitán Prat: Reserva Nacional Tamango, February 2001, W. Quilhot 3005, 3058 (UV).

Menegazzia magellanica R. Sant., Arkiv för Botanik 30A, 11: 21 (1942).

Type: Chile, Punta Arenas, 1896, P. Dusén 4b (S !, holotype).

Menegazzia magellanica is endemic to southernmost South America. It has a greyish-green, smooth upper surface, convex, slightly pruinose and maculate lobes, and maniciform soralia with an open duct to the cavity. Menegazzia magellanica occasionally produces apothecia with two-spored asci. Bjerke \& Elvebakk (2001, pp. 382-383) erronously stated that it has eight spores in the asci, but as commented elsewhere in the same paper, M. magellanica belongs to the subgenus Dispora. It is discussed in detail by Santesson (1942), Calvelo \& Adler (1994), Bjerke \& Elvebakk (2001) and Bernasconi et al. (2002).
Chemistry: atranorin, stictic acid, constictic acid, cryptostictic acid, menegazziaic acid.

Distribution: in Chile between latitude 50 50 '

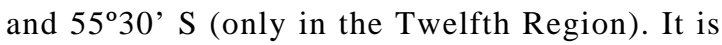
also known from Argentina (Calvelo \& Adler 1994) and South Georgia (Bjerke \& Elvebakk 2001). Several unpublished specimens from re-

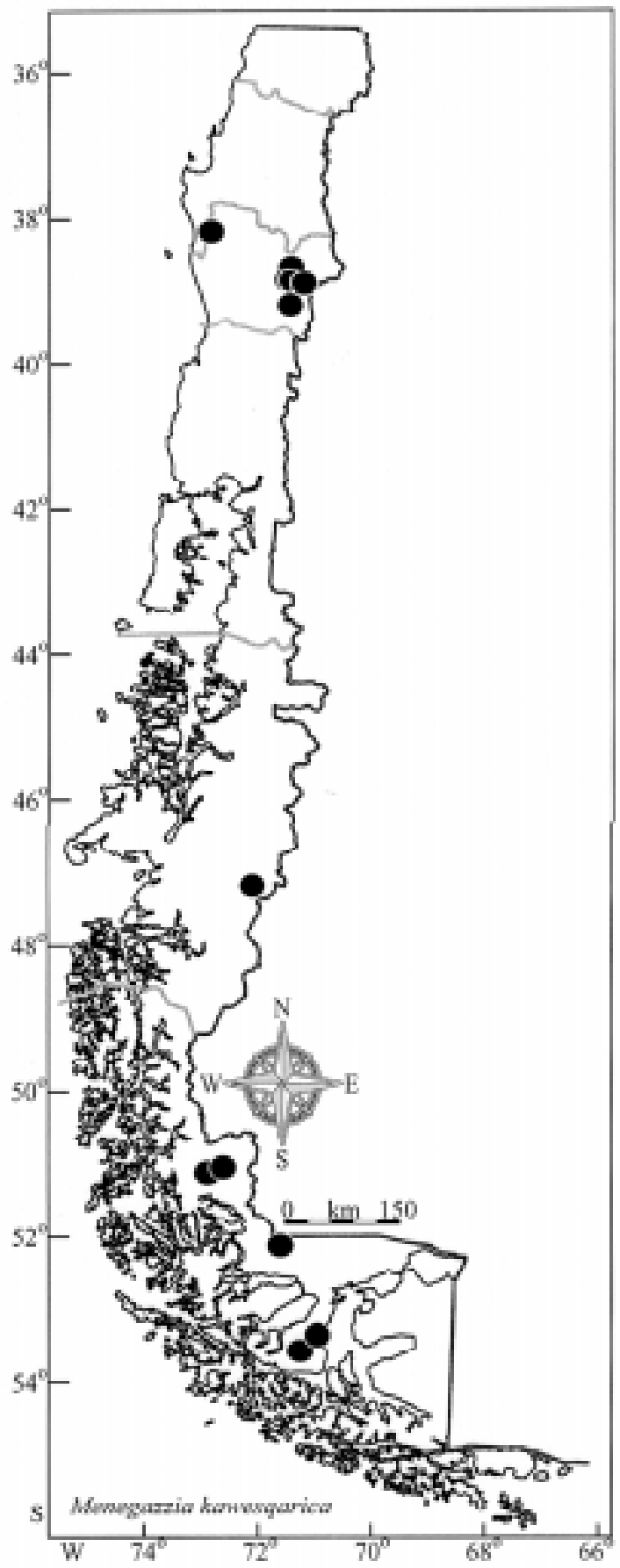

Fig. 4: Distribution of Menegazzia kawesqarica in Chile.

Distribución de Menegazzia kawesqarica en Chile. 
gions Eight to Eleven identified as M. magellanica were seen. These were referable to $M$. wandae and $M$. neozelandica, in particular. For distribution map, morphological variation, habitat ecology and list of examined specimens, see Bjerke \& Elvebakk (2001). It is, however, slightly less variable than stated by Bjerke \& Elvebakk (2001), because some problematic specimens assumed to belong to $M$. magellanica are here redetermined to $M$. neozelandica after comparison with more specimens of the latter species (see below).

Specimens examined: 105. See also Bjerke \& Elvebakk (2001).

Menegazzia neozelandica (Zahlbr.) P. James, Flora of Australia 54: 313 (1992).

Parmelia nigrescens Stirt., Scottish Naturalist (Perth) 4: 253 (1878) non. Ach. - Parmelia neozelandica Zahlbr., Catalogus Lichenum Universalis 6: 53 (1930). - Menegazzia circumsorediata R. Sant., Arkiv för Botanik 30A, 11: 14 (1942). - Menegazzia nigrescens (Stirt.) R. Sant., Arkiv för Botanik 30A, 11: 13 (1942).

Type: New Zealand, Wellington, J. Buchanan (BM!, holotype).

Menegazzia neozelandica has a convex, glossy upper surface, numerous gaping perforations with elevated rims, and soralia that mainly surround the perforations. It is a widespread pan-austral species, and is discussed in detail by Santesson (1942, as M. circumsorediata), James \& Galloway (1992), Calvelo \& Adler (1994), Bjerke \& Elvebakk (2001) and Bernasconi et al. (2002), and is illustrated in Beltman (1978), in James \& Galloway (1992) and in Bjerke \& Elvebakk (2001).

Chemistry: atranorin, stictic acid, cryptostictic acid, constictic acid and menegazziaic acid.

Variation: Menegazzia neozelandica has a rather constant morphology apart from the soralia, which occasionally are not associated with perforations, especially in small thalli. The soralia that do not surround perforations are subcapitate, and resemble the soralia of several other species. In particular, specimens from near the limits of its Chilean distribution range and specimens encircling tiny twigs deviate by having many soralia not associated with perforations. A specimen (A. Elvebakk 98: 255) identified as $M$. magellanica by Bjerke \& Elvebakk (2001) is here redetermined to $M$. neozelandica because of elevated rims, a shining upper surface, and a few soralia surrounding perforations, which were previously considered true maniciform soralia.

Distribution: It has a disjunct distribution in Chile (Fig. 5). It is known from latitude $30^{\circ} 30^{\prime} \mathrm{S}$ (Fray Jorge, Fourth Region). It is so far not known from the area between Fray Jorge and Lago
Lleulleu (Eighth Region). It has a more or less continuous distribution from latitude $38^{\circ} 20^{\prime} \mathrm{S}$ to latitude 52 $40^{\circ}$ 'S (Isla Riesco, Twelfth Region). It is also present on Islas Juan Fernández. It is much more common in Chile than previously expected (see Bjerke \& Elvebakk 2001). These are the first

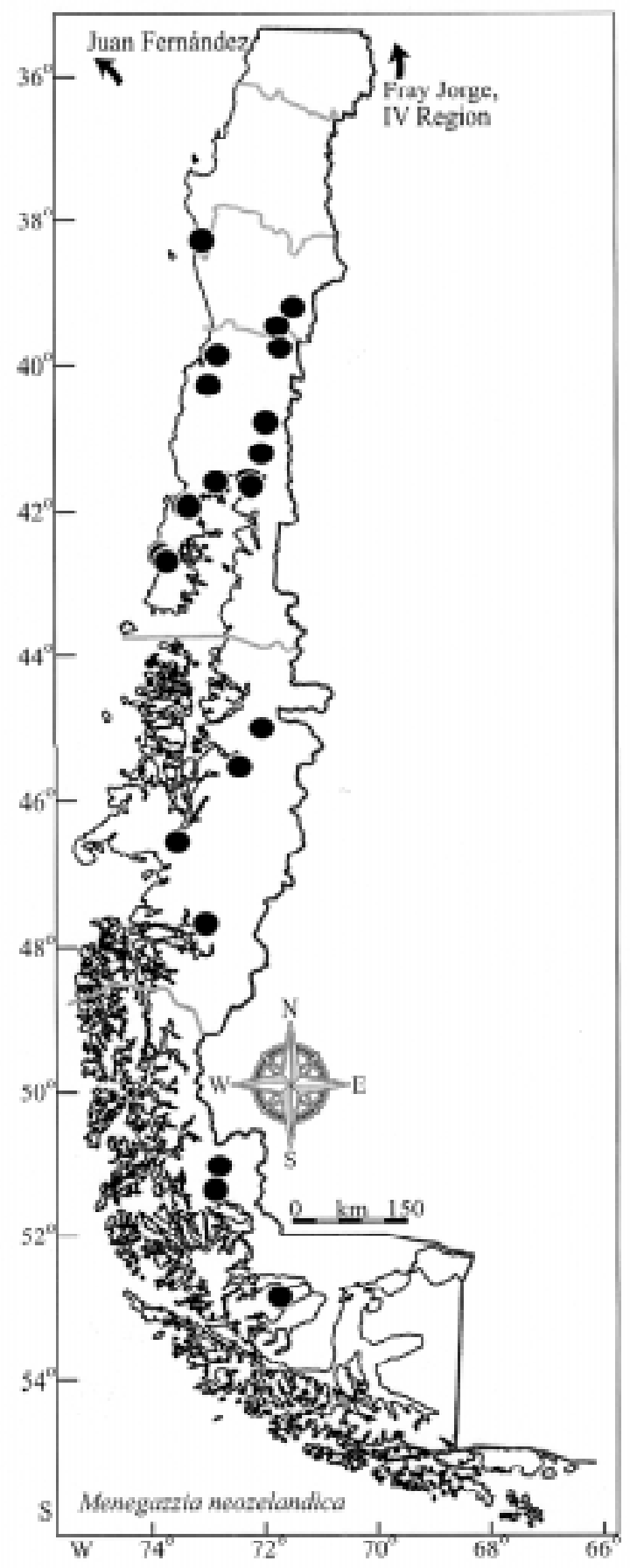

Fig. 5: Distribution of Menegazzia neozelandica in Chile.

Distribución de Menegazzia neozelandica en Chile. 
records from Islas Juan Fernández and from the mainland north of latitude $45^{\circ} 30^{\prime} \mathrm{S}$, and it is the only species of Menegazzia known from the marginal and relict forests of Fray Jorge and from the isolated archipelago of Juan Fernández. It is also known from a few localities in Argentina (Calvelo \& Adler 1994), from Tasmania (James \& Galloway 1992), and from New Zealand (Galloway 1985).

Habitat ecology: Menegazzia neozelandica is an epiphyte of trees and shrubs in Valdivian rainforests in moderate to dense shade, often growing intermixed with mosses, Hymenophyllum ferns, and other lichens. When growing on trunks of tall trees it is often more attached to other epiphytes than directly to the bark. Its occurrence on erect Hymenophyllum shoots is very striking, and it is a first-successional species, producing numerous small thalli; and locally as the most common pioneer species in such habitats. When attached directly to bark, it prefers branches of smooth-barked species such as Amomyrtus luma, A. meli, Laurelia phillipiana, Aextoxicon punctatum, Tepualia stipularis, Gaultheria mucronata, Embothrium coccineum, Drimys winteri, Berberis spp., Kageneckia oblonga (Fray Jorge), Baccharis sp., Ovidia pillo-pillo and Rhaphithamnus spinosus. It is also found on Nothofagus, e.g., N. nitida, N. dombeyi, N. betuloides, $N$. antarctica and $N$. alpina, and on planted Populus along roadsides on Chiloé. One single specimen was found on a rock at the forest floor. It associates particularly with shade-loving lichens with cyanobacterial photobionts, such as Degelia gayana, Leioderma pycnophorum, Pseudocyphellaria bartlettii, P. intricata, Leptogium spp., Nephroma plumbeum, Sticta hypochra, S. fuliginosa and S. caulescens. According to Redon et al. (1975), it associates with Sticta fuliginosa, S. weigelii, Pseudocyphellaria crocata, P. mallota and Hypogymnia sp. in Fray Jorge. It has an altitudinal range from sea level to ca. $700 \mathrm{~m}$, and is by far most common at lower altitudes.

Selected specimens examined (total 59). Chile, Fourth Region of Chile, Province of Limarí: Parque Nacional Fray Jorge, 7 December 1974, J. Redon, W. Quilhot (3026, 3040, 3043) \& G. Guzmán (UV), October 1991, W. Quilhot 1866, 3034 (UV). Fifth Region of Chile, Islas Juan Fernández: Masatierra, 20 December 1916, C. \& I. Skottsberg 4;435 (GB 2173-2); Salsipuedes, August 1975, W. Quilhot 1306 (UV). Eighth Region of Chile, Province of Arauco: Lago Lleulleu, 17 January 1998, W. Quilhot 3031 (UV). Ninth Region of Chile, Province of Cautín: Parque Nacional Huerquehue, 23 November 1986, W.
Quilhot 3042 (UV). Tenth Region of Chile, Province of Valdivia: Cordillera Pelada, 19 December 1977, W. Quilhot 1850 (UV); ca. 3 km E of Lago Riñihue and 2-3 km N of Enco, 30 November 2001, J. W. Bjerke 1528/01 (TROM). Tenth Region of Chile, Province of Osorno: Parque Nacional Puyehue, Antillanca, 16 February 1980, W. Quilhot 3032 (UV). Tenth Region of Chile, Province of Llanquihue: Parque Nacional Vicente Pérez Rosales, southern slope of Volcán Osorno, 21 February 2001, J. W. Bjerke 739/01 (TROM); $1 \mathrm{~km}$ NW of Caleta La Arena, 23 February 2001, J. W. Bjerke 753/01, 757/01, 767/01, 794/01, 796/01, 816/01 (UV), 813/01 (TROM); 15 km W of Puerto Montt, Puente Taylor, 17 November 2000, A. Elvebakk 00:431 A, 00:438, 00:441A, B (TROM). Tenth Region of Chile, Province of Chiloé: 1-2 km E of Ancud, 17 November 2000, A. Elvebakk 00:452 (TROM); Cucao, Parque Nacional de Chiloé, near the Guardería, 18 November 2000, A. Elvebakk 00:486, 00:490, 00:491, 00:492, 00:493, 00:495, 00:537C, 00:540B, 00:541, 00:542C, 00:552 (TROM); HuillincoCucao, 14 February 1984, W. Quilhot 3024, 3038, 3039 (UV). Eleventh Region of Chile, Province of Aisén: Lago Riesco, $10 \mathrm{~km} \mathrm{~S}$ of Puerto Aisén, November 1993, W. Quilhot 1374, 3033 (UV); Parque Nacional Laguna San Rafael, November 1997, W. Quilhot 3035 (UV). Eleventh Region of Chile, Province of Capitan Prat: El Vagabundo, $100 \mathrm{~km} \mathrm{~S}$ of Cochrane, 26 February 2002, W. Quilhot 2073 (UV). Twelfth Region of Chile, Province of Última Esperanza: Parque Nacional Torres del Paine, Refugio Zapata, 28 February 1998, A. Elvebakk 98:255 \& J. W. Bjerke (TROM).

Menegazzia norsorediata Adler \& Calvelo, Mycotaxon 59: 368 (1996).

Type: Argentina, Province of Tierra del Fuego, $10 \mathrm{~km}$ from the intersection of Moat River and the route from Moat to Ushuaia, November 1993, S. Calvelo \& M. Adler (BAFC 37732, holotype).

Menegazzia norsorediata is a southern South American endemic species. It has greyish-green shining lobes that are generally epruinose and slightly maculate, evenly distributed perforations with flat or elevated rims, and convex, wellseparated soralia with orange patches. It is chemically distinct from other South American species.

Chemistry: atranorin, norstictic acid and connorstictic acid.

Variation: Menegazzia norsorediata shows some minor morphological variation. Some thalli produce several sympodial, toe-like branches, but generally, these are absent. Large thalli growing on trunks often have radiating lobes with perforations lined on parallel lobes, whereas on twigs, 
the lobes are more complexly divided. The size and colour of soralia vary with age and habitat. Young soralia are small and with a greenish hue in fresh conditions. Apothecia are rare.

Distribution: In Chile known from latitude $37^{\circ} 49^{\prime}$ S (Nahuelbuta, Ninth Region) to $53^{\circ} 22^{\prime} \mathrm{S}$ (Península Brunswick, Twelfth Region) (Fig. 6). It is also known from Argentina (Adler \& Calvelo 1996).

Habitat ecology: Menegazzia norsorediata is a common epiphyte of trees and shrubs in both Valdivian rainforest and high-altitude mixed deciduous-coniferous forest, in microhabitats with variable light conditions. In Petrohué (Tenth Region), it is common both on open twigs of isolated trees of Nothofagus pumilio and N. dombeyi at the forest edge, and on myrtaceous shrubs in the understorey vegetation of well-developed $N$. dombeyi forests permitting little direct solar radiation to reach the lower strata. It is among the first macrolichens to colonise the bark of young shrubs and trees. Other known phorophytes are $N$. alpina, $N$. nitida, $N$. betuloides, $N$. antarctica, Podocarpus alpinus, planted Pinus, Drimys winteri, Embothrium coccineum, Euchryphia cordifolia, Gevuina avellana, Weinmannia trichosperma, Berberis ilicifolia and Maytenus magellanica. It has a wide altitudinal range from sea level on Chiloé and in Laguna San Rafael to $1,400 \mathrm{~m}$, and probably higher in and around Conguillío. Since it has a wide ecological amplitude, it associates with many different species. However, it prefers smooth bark, and is only rarely found in close association with broad-lobed species of Sticta and Pseudocyphellaria that prefer more roughened bark.

Selected specimens examined (total 74): Chile: Ninth Region, Province of Malleco: Malalcahuello, 12 October 1987, W. Quilhot 2000, 2006 (UV \& TROM), 2008, 3103, 3080, 3176 (UV). Ninth Region of Chile, Province of Cautín: Parque Nacional Conguillío, Cabañas La Baita, 29 November 2001, J. W. Bjerke 1410/01, 1420A/ 01, 1423/01, 1427/01, 1433/01 (TROM); Parque Nacional Huerquehue, 23 November 1986, W. Quilhot 3052, 3056 (UV). Tenth Region of Chile, Province of Valdivia: Cordillera Pelada, 19 December 1977, W. Quilhot 3104 (UV). Tenth Region of Chile, Province of Osorno: Parque Nacional Puyehue, Lago Bertín, 20 November 1979, W. Quilhot 3051 (UV). Tenth Region of Chile, Province of Llanquihue: Parque Nacional Vicente Pérez Rosales, between Petrohué and Volcán Osorno, 20-21 February 2001, J. W. Bjerke 523/01, 547A/01, 610/01 (TROM), 547B/01 (S), 559/01 (HO), 509/01, 639/01, 709/01 (UV); Lago Chapo, November 1992, W. Quilhot 3082, 3100
(UV); $40 \mathrm{~km} \mathrm{SW}$ of Puerto Montt, $3 \mathrm{~km} \mathrm{NE}$ of Puente los Palos, 17 November 2000, A. Elvebakk 00:443 (TROM). Tenth Region of Chile, Province of Chiloé: Cucao, Parque Nacional de Chiloé, near Guardería, 18 November 2000, A. Elvebakk 00:540A (TROM). Tenth Region of Chile, Prov-

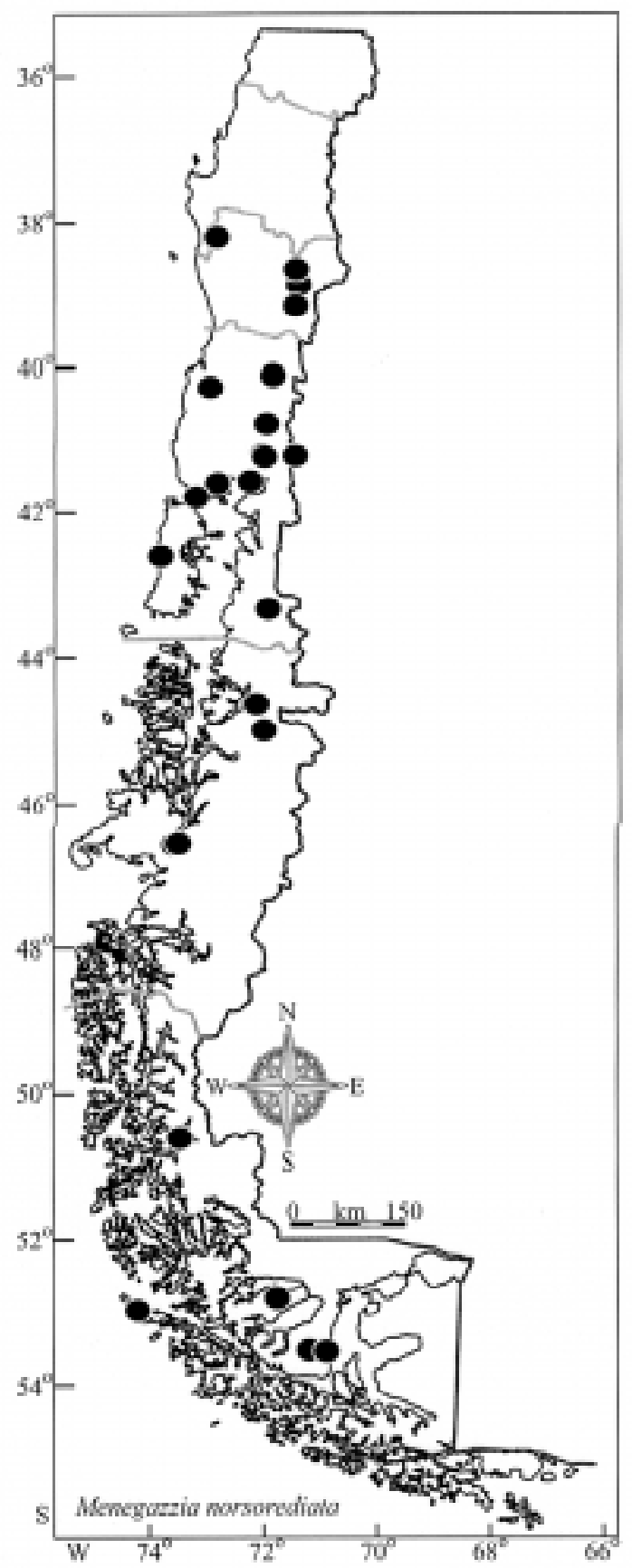

Fig. 6: Distribution of Menegazzia norsorediata in Chile.

Distribución de Menegazzia norsorediata en Chile. 
ince of Palena: Lago Yelcho, Playa Cavi, 28 November 1993, W. Quilhot s.n., 1806 (UV). Eleventh Region of Chile, Province of Aisén: Parque Nacional Queulat, 24 November 1993, W. Quilhot 3102 (UV); Parque Nacional Laguna San Rafael, November 1997, W. Quilhot 1448, 1449, 1450, 1458, 1480, 1481, 1640, 1641, 1645, 1646, 3054, 3084, 3098 (UV).

Menegazzia sanguinascens (Räsänen) R. Sant., Arkiv för Botanik 30A, 11: 28 (1942).

Parmelia sanguinascens Räsänen, Annales Botanici Societatis Zoologica Botanica Fennicae Vanamo 2, 1: 18 (1932). - Parmelia opuntioides var. vulgaris Räsänen, Annales Botanici Societatis Zoologica Botanica Fennicae Vanamo 2, 1: 18 (1932). - Parmelia opuntioides var. violascens Räsänen, Annales Botanici Societatis Zoologica Botanica Fennicae Vanamo 2, 1: 18 (1932). Parmelia alboffii (Zahlbr.) DR in R. Sant., Arkiv för Botanik 30A, 11: 28 (1942). - Parmelia dispora var. alboffii Zahlbr., Kungliga Svenska Vetenskapsakademiens Handlingar 57, 6: 39 (1917).

Type: Chile, Isla Grande, Fiordo de Agostini, 22 February 1929, H. Roivainen s.n. (H, holotype; S !, syntype).

This characteristic austral species has broad, shining and emaculate lobes, few to numerous toe-like lateral branches, and neat, convex soralia that are UV+ white. It is often prominently green when wet and fresh, and has small, gaping perforations with slightly elevated margins. It is discussed in detail and illustrated in Santesson (1942), in Calvelo \& Adler (1994) and in Bjerke \& Elvebakk (2001). Santesson (1942) had a wide interpretation of this species, including in his list of examined specimens material that has proven to be morphologically and chemically different from $M$. sanguinascens s. str.

Chemistry: atranorin, hypothamnolic acid and thamnolic acid.

Variation: As stated by Bjerke \& Elvebakk (2001), M. sanguinascens is a variable species in terms of its lobe size and morphology, colour of the upper surface, and number and position of the soralia. These features vary with microclimatic conditions. This being said, material from regions Nine to Eleven has a quite uniform morphology and colour, and is easily distinguished from the other sorediate species of Menegazzia. Thus, most variability is seen in the southernmost populations.

Distribution: In Chile from latitude $37^{\circ} 49^{\prime} \mathrm{S}$ (Nahuelbuta, Ninth Region) to $55^{\circ} 30^{\prime} \mathrm{S}$ (Isla Hoste, Twelfth Region) (Fig. 7). It is common in Argentina (Calvelo \& Adler 1994, Bernasconi et al. 2002), and is also reported from Macquarie Island south of mainland Australia (Filson 1996).

Habitat ecology: Menegazzia sanguinascens is a prominent epiphyte of trees in moderately to deeply shaded forests of moderate to high humid

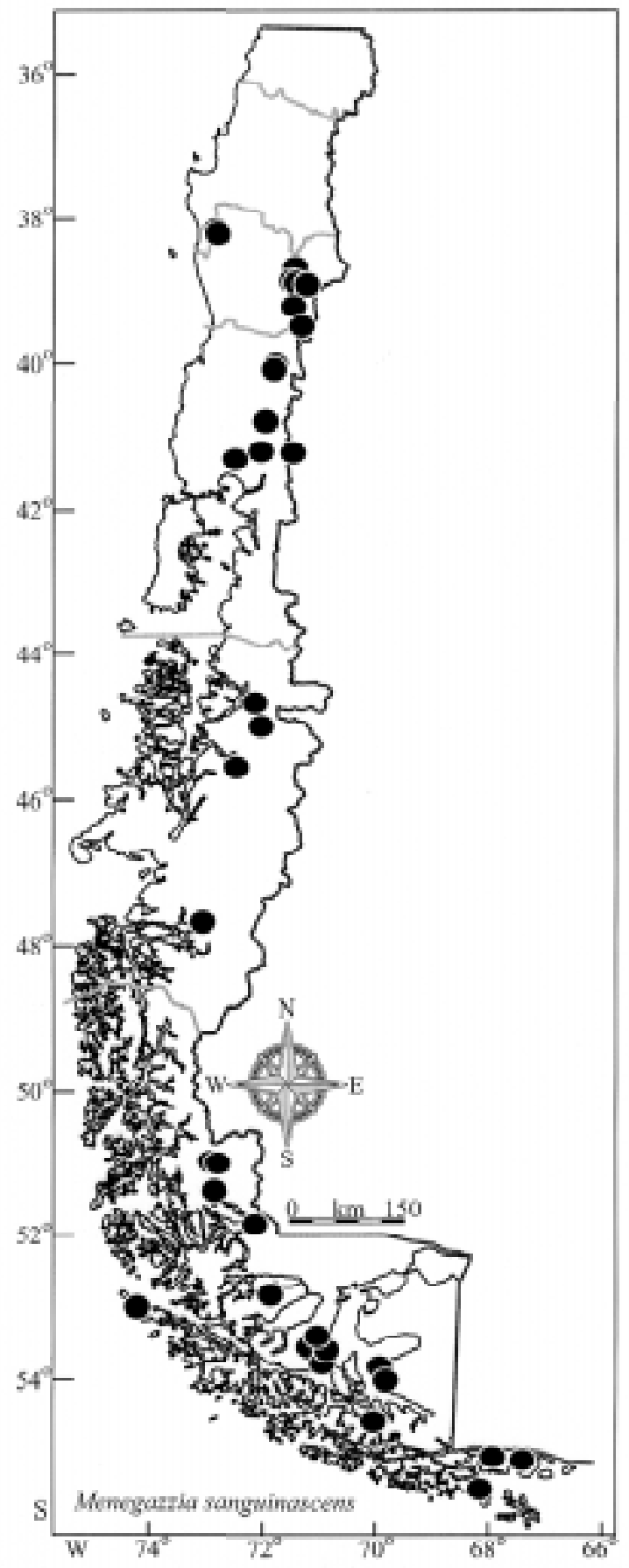

Fig. 7: Distribution of Menegazzia sanguinascens in Chile.

Distribución de Menegazzia sanguinascens en Chile. 
ity. It prefers trunks of large trees and is often seen as large, overlapping rosettes on the following phorophytes: Nothofagus alpina, N. dombeyi, $N$. pumilio, N. betuloides, N. antarctica, Araucaria araucana, Podocarpus alpinus, $P$. salignus and Drimys winteri. It occasionally inhabits the branches of the same phorophytes. It associates with the following lichens: Menegazzia chrysogaster, M. albida, M. hollermayeri, M. norsorediata, $M$. tenuis, $M$. wandae, Pseudocyphellaria encoensis, P. piloselloides, Psoroma pallidum, P. leprolomum, Coccotrema coccophorum, Platismatia glauca, Sticta hypochra and Erioderma leylandii. On one occasion it was collected from a rock on the forest floor, but it was not in direct contact with the rock, only overgrowing bryophytes and other lichens. It is so far not collected close to the coast north of the Twelfth Region. For instance, none of the many examined specimens from Laguna San Rafael, Chiloé and Caleta La Arena proved to be $M$. sanguinascens. It has an altitudinal range from $100 \mathrm{~m}$ to at least $1,400 \mathrm{~m}$ in regions Nine to Eleven.

Selected specimens examined (total 89): Chile: Ninth Region, Province of Malleco: Malalcahuello, 12 October 1987, W. Quilhot 1846, 1864 (UV); Parque Nacional Nahuelbuta, between Centro de Informaciones and Piedra del Águila, 27 February 2001, J. W. Bjerke 916/01 (TROM), 942/01 (UV). Ninth Region of Chile, Province of Cautín: Parque Nacional Conguillío, 19 December 1978, W. Quilhot 3044, 3049 (UV); Parque Nacional Huerquehue, 20 November 1986, W. Quilhot 1856, 3044 (UV); Parque Nacional Villarica, 11 December 1983, W. Quilhot 1847 (UV). Tenth Region of Chile, Province of Valdivia: Enco-Choshuenco, 17 November 1984, W. Quilhot 1835, 3047 (UV). Ninth Region of Chile, Province of Osorno: Parque Nacional Puyehue, Antillanca, 2 December 1986, B. Coppins, D. Galloway, G. Guzmán \& P. James $4542(\mathrm{H})$. Ninth Region of Chile, Province of Llanquihue: Cuesta Bellavista, El Mirador, April 1974, J. Redon 03041 (UV 1841); Parque Nacional Vicente Pérez Rosales, southern slope of Volcán Osorno, 21 February 2001, J. W. Bjerke 655/01 (HO). Eleventh Region of Chile, Province of Aisén: Parque Nacional Queulat, 24 November 1993, W. Quilhot 1870 (UV); Lago Riesco, 10 km S of Puerto Aisén, 12 February 1985, W. Quilhot 1855 (UV). Eleventh Region of Chile, Province of Capitán Prat: El Vagabundo, $100 \mathrm{~km} \mathrm{~S}$ of Cochrane, 26 February 2002, W. Quilhot 3072 (UV). Twelfth Region of Chile, Province of Magallanes: Isla Desolación, Puerto Angosto, 16 April 1896, P. Dusén s.n. (S L11550).
Menegazzia subpertusa P. James \& D. J. Galloway, New Zealand Journal of Botany 21: 195 (1983).

Type: New Zealand, Rangitikei Gorge, Wellington, 17 June 1980, J. K. Bartlett (BM, holotype).

This widespread Australasian species is here reported for the first time from America. Detailed descriptions are given in Galloway (1985) and James \& Galloway (1992). It is illustrated in James \& Galloway (1992) and in Kantvilas \& Jarman (1999).

Chemistry: atranorin, stictic acid, menegazziaic acid, cryptostictic acid and constictic acid.

Variation and distinguishing features: Menegazzia subpertusa is characterised by a closely attached thallus with convex, irregularly spreading and often imbricate lobes, small perforations with flat rims, and laminal, convex soralia that are often in groups. Single soralia are small, generally not wider than $0.5 \mathrm{~mm}$. The upper surface is minutely pruinose in parts, smooth, pale grey and often with slightly shining apices. Apothecia containing numerous two-spored asci are common. It is distinguished from M. kawesqarica, which has slightly convex, reticulately maculate, corrugate and dull lobes, and large convex soralia that are readily confluent and spread over the upper surface. Apothecia with mature asci are not known in M. kawesqarica. They also inhabit different habitats. Menegazzia neozelandica is distinct from $M$. subpertusa by the soralia that are surrounding perforations. However, as stated under M. neozelandica above, it occasionally has soralia that are convex and not associated with perforations. Furthermore, M. subpertusa sometimes has soralia with a central opening, resembling the soralia of $M$. neozelandica or $M$. magellanica. The specimen illustrated by James \& Galloway (1992, p. 243) actually has one such soralium. In such cases, M. neozelandica is distinct by the glossier lobes, the elevated rims of perforations, the absence of pruina and maculae, and at least some soralia associated with perforations. The more typical convex soralia of $M$. subpertusa are illustrated in Kantvilas \& Jarman (1999). Specimens of M. subpertusa were identified as M. sanguinascens by Santesson (1942), e.g., H. Roivainen s.n., 12.IV.1929. Menegazzia subpertusa is distinct from $M$. sanguinascens, which has a shiny upper surface, broad, greygreen lobes, and hypothamnolic and thamnolic acids as the major medullary constituents.

Distribution: in South America from latitude $36^{\circ} 50^{\prime} \mathrm{S}$ (Las Trancas, Eighth Region of Chile) to 544ㅇ' S (Isla de los Estados, Argentina) (Fig. 8). The Argentinean localities reported here are not 
included in the map. It is not known south of latitude $46^{\circ} 40^{\prime} \mathrm{S}$ in Chile.

Habitat ecology: Menegazzia subpertusa is mainly found growing on sclerophyll bushes and scrubs in rather sunny and dry microhabitats surrounded by well-developed forests, e.g., along forest edges, river beds and bogs, and not so much on

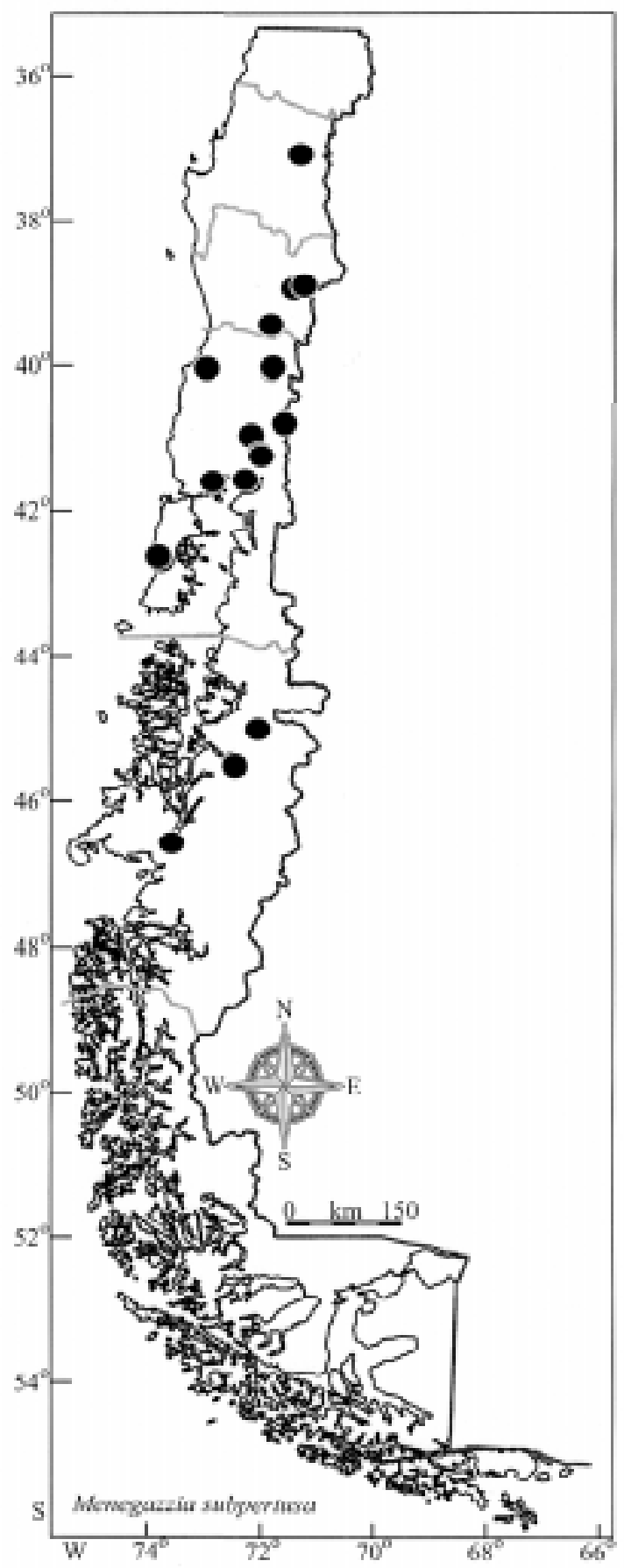

Fig. 8: Distribution of Menegazzia subpertusa in Chile.

Distribución de Menegazzia subpertusa en Chile. trees in typical forest vegetation. It prefers smooth bark, such as on young twigs, where it encircles the twigs, so that lobe apices from the same thallus meet and compete for space. It is known from the following phorophytes: Ugni molinae, Berberis spp., Amomyrtus spp., Nothofagus nitida, $N$. pumilio, $N$. betuloides, N. obliqua, Cryptocarya alba, Azara spp., Baccharis spp. and Embothrium coccineum. It associates with other light-tolerant lichens, such as Protousnea spp. Usnea spp., Cetrariastrum sorocheilum, leprose crustose lichens, Hypogymnia subphysodes, Hypotrachyna sinuosa, $H$. brevirhiza, $H$. densirhizinata, $H$. cf. revoluta, Rimelia reticulata, Physcia sp., Punctelia stictica, Ramalina celastri, Psoroma leprolomum, Haematomma alpina and Nephroma cellulosum. It is often a pioneer species, only associated with a few crustose lichens. It has an altitudinal range from sea level (Chiloé, Isla de los Estados) to 1,500 m (Chillán, the Conguillío area).

Selected specimens examined (total 35): Chile: Eighth Region, Province of Nuble: Recinto, Las Trancas, 12 April 1929, H. Roivainen s.n. (S). Ninth Region of Chile, Province of Cautín: $1 \mathrm{~km} \mathrm{~N}$ of crossroad S of Parque Nacional Conguillío, 28 November 2001, J. W. Bjerke 1405A/01 (TROM); ca. halfway between Melipeuco and Icalma, 28 November 2001, J. W. Bjerke 1363/01 (TROM). Tenth Region of Chile, Province of Valdivia: Piedra Blanca, 14 September 1940, R. Santesson 7785 (S); Enco, Choshuenco, 11 November 1987, W. Quilhot 1865 (UV); ca. $3 \mathrm{~km}$ E of Lago Riñihue and 2-3 km N of Enco, 30 November 2001, J. W. Bjerke 1506/01, 1520/01, 1532/01, 1537/01 (TROM). Tenth Region of Chile, Province of Osorno: Lago Rupanco, February 1984, W. Quilhot 1848 (UV). Tenth Region of Chile, Province of Llanquihue: Parque Nacional Vicente Pérez Rosales, southern slope of Volcán Osorno, 21 February 2001, J. W. Bjerke 736/01 (TROM); Parque Nacional Vicente Pérez Rosales, Lago Todos Los Santos, Petrohué, A. Elvebakk 00:580 (TROM); Lago Chapo, November 1992, W. Quilhot 1867 (UV); $15 \mathrm{~km} \mathrm{~W}$ of Puerto Montt, Puente Taylor, 17 November 2000, A. Elvebakk 00:420 (TROM). Tenth Region of Chile, Province of Chiloé: Cucao, Parque Nacional de Chiloé, near Guardería, 18 November 2000, A. Elvebakk 00:494, 00:537B, 00:540C (TROM); Huillinco-Cucao, 14 February 1984, W. Quilhot 1798, 1849, 1851, 1852A (UV), 1853, 3023 (UV \& TROM). Eleventh Region of Chile, Province of Aisén: Carretera Austral, November 1993, W. Quilhot 1375A (UV); Lago Riesco, $10 \mathrm{~km} \mathrm{~S}$ of Puerto Aisén, 22 November 1993, W. Quilhot 1794, 1868A (UV). Eleventh Region of Chile, Province of Capitan Prat: Parque Nacional Laguna San Rafael, November 1997, W. 
Quilhot 3027 (UV). Argentina: Province of Tierra del Fuego: Isla de Los Estados, Bahía Capitan Canepa, 4 November 1971, H. Imshaug 53055 \& K. Ohlsson [admixed with and labelled Psoroma leprolomum] (MSC 116111); Isla de Los Estados, Bahía Crossley, 18 October 1971, H. Imshaug $50877 \&$ K. Ohlsson [admixed with and labelled Psoroma leprolomum] (MSC 11701).

Menegazzia tenuis R. Sant., Arkiv för Botanik 30A, 11: 27 (1942).

Type: Chile, Isla Desolación, Puerto Angosto, 1896. P. Dusén 228a (S !, holotype).

This southern South American endemic is characterised by narrow, sinuous lobes, numerous ellipsoid perforations, and small, maniciform soralia containing few soralia. It is discussed in detail and illustrated in Santesson (1942) and Bjerke \& Elvebakk (2001).

Chemistry: atranorin, lichesterinic acid and protolichesterinic acid.

Variation: It has a uniform morphology apart from the blackening or browning of margins that centrally occasionally extends to upper side of the lobes, and the size of the perforations, which ranges from $0.15 \mathrm{~mm}$ diam at young lobes to 1.0 $\mathrm{mm}$ diam at older lobes.

Distribution: Its main distribution area is in southernmost Chile and Argentina south of latitude 52 $40^{\prime}$ 'S (Bjerke \& Elvebakk 2001). It is also known from one locality in the Ninth Region of Chile at latitude $38^{\circ} 49^{\prime} \mathrm{S}$ (Fig. 9).

Habitat ecology: Menegazzia tenuis occurs in intermediate to deep shade in habitats of high humidity, amongst mosses and other shade-loving lichens on bark of Nothofagus dombeyi, N. betuloides, $N$. pumilio and $N$. antarctica. At 1,400 $\mathrm{m}$ of altitude, between Melipeuco and Icalma (Ninth Region), some trees of $N$. dombeyi were inclining above a brook. Menegazzia tenuis was growing on the shaded lower side of these trees receiving much humidity from the slowly running water. It associates with $M$. albida, $M$. sanguinascens, Sticta hypochra, Platismatia glauca (small thalli), Bacidia sp., in addition to several mosses and leprose crustose lichens. It has an altitudinal range from sea level to $200 \mathrm{~m}$ in Twelfth Region of Chile.

Selected specimens examined (total 11): Chile: Ninth Region, Province of Cautín: ca. halfway between Melipeuco and Icalma, 28 November 2001, J. W. Bjerke 1366/01, 1384/01 (TROM). Twelfth Region of Chile, Province of Magallanes: Península Brunswick, $6 \mathrm{~km} \mathrm{~S}$ of Fuerte Bulnes, 28 January 1989, M. Wedin 1255 (UPS 40596).
Menegazzia wandae Bjerke, Lichenologist 33: 117 (2001).

Type: Chile, Décima Región, Valdivia, Cordillera Pelada, en bosque de raulí, 19 December 1977, W. Quilhot 1815 (UV !, holotype; TROM !, isotype).

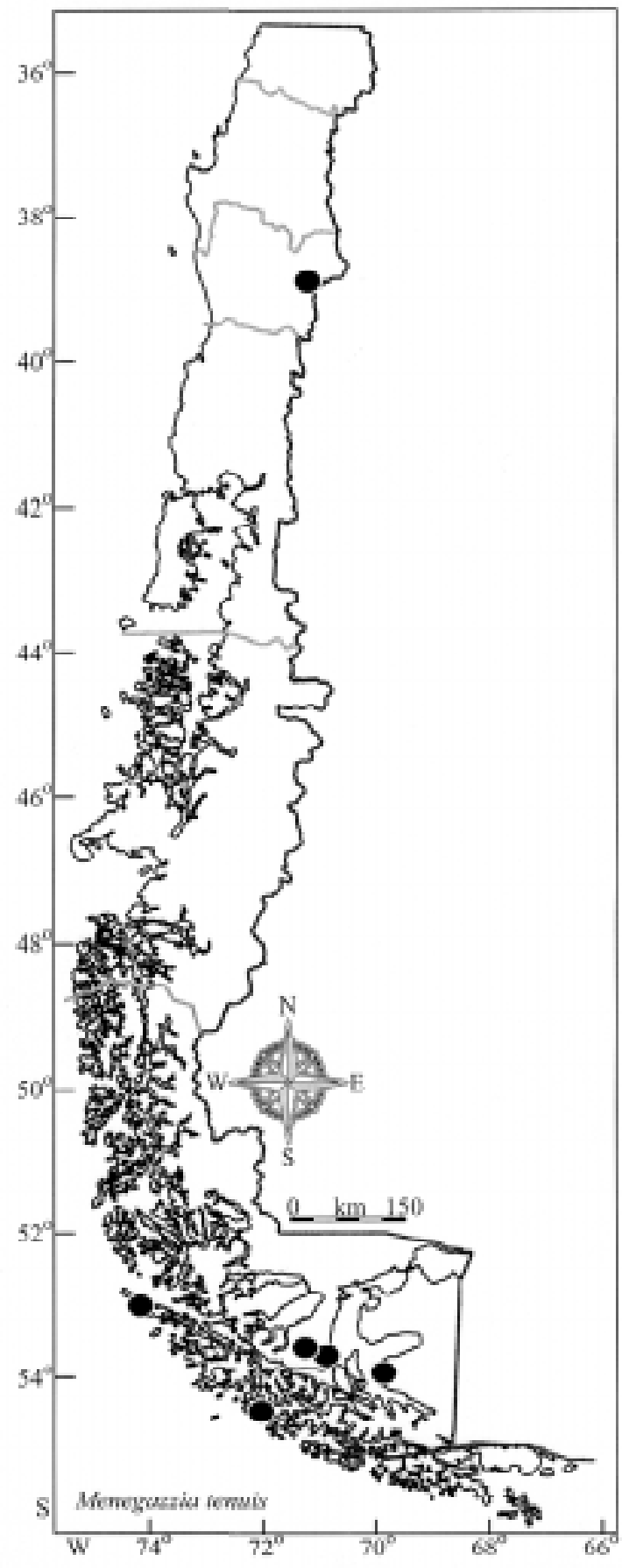

Fig. 9: Distribution of Menegazzia tenuis in Chile. Distribución de Menegazzia tenuis en Chile. 
This Chilean endemic species has convex, wideangled lobes with prominent brown-black margins, and tall sorediate pustules with lacerate flange-like margins.

Chemistry: atranorin and thamnolic acid.

Variation: Menegazzia wandae shows some minor morphological variation. The colour of the upper surface varies from greyish-white in more exposed habitats and in old material to greyishgreen in shaded habitats and fresh material. Central lobes are generally paler than younger lobes, and in some occasions, it seems like the photobiont is dying centrally. The dark margins are not prominent in all lobes. Soralia are formed on pustules that vary in size, from 0.6 to $1.5 \mathrm{~mm}$ tall, and young, immature soralia have entire margins, and therefore resemble the pustules of $M$. fumarprotocetrarica.

Distribution: in Chile from latitude $38^{\circ} 30^{\prime} \mathrm{S}$ (Malalcahuello, Ninth Region) to latitude $46^{\circ} 40^{\prime}$ S (Laguna San Rafael, Eleventh Region). It occurs along both mountain chains (but not in Nahuelbuta), and in lowland areas between them (Fig. 10). It is still not known from Argentina. It has the most restricted distribution range of the species treated here.

Habitat ecology: Menegazzia wandae is an epiphyte of trees and shrubs in humid rainforests and is best developed in habitats of rather low light intensity, such as in lowland Valdivian forests. It is known from the following phorophytes: Nothofagus dombeyi, $N$. nitida, $N$. alpina, $N$. betuloides, Amomyrtus luma, A. meli, Drimys winteri, Embothrium coccineum, Myrceugenia exsucca, Lomatia ferruginea, Fitzroya cupressoides, Austrocedrus chilensis, Gevuina avellana, and several myrtaceous shrubs. It often grows close to the base or on fallen, horizontal trunks where it competes with mosses and Hymenophyllum ferns. It associates with Menegazzia albida, M. sanguinascens, $M$. hollermayeri, Coccotrema coccophorum, Erioderma leylandii, Sticta caulescens, $S$. hypochra, S. fuliginosa (as 'Dendriscocaulon'), Nephroma australe, Pseudocyphellaria nitida, $P$. pluvialis and Psoroma pallidum. It was found from sea level (Chiloé, Caleta La Arena) to $900 \mathrm{~m}$ (Conguillío, Huerquehue).

Selected specimens examined (total 44): Chile: Ninth Region, Province of Cautín: Parque Nacional Conguillío, 12 May 2000, W. Quilhot 3091 (UV); Parque Nacional Huerquehue, 23 November 1986, W. Quilhot 1802, 1837B, 3066 (UV). Tenth Region of Chile, Province of Valdivia: Cordillera Pelada, 5 December 1985, W. Quilhot 1801, 1814A (UV); Salto del Huilo Huilo, 17 November 1984, W. Quilhot 1793 (UV).
Tenth Region of Chile, Province of Llanquihue: Puerto Manzano, 27 April 1974, J. Redon s.n. (UV 3109); Parque Nacional Vicente Pérez Rosales, between Petrohué and Volcán Osorno, 20-21 February 2001, J. W. Bjerke 502/01 (UV), 733/01 (TROM); 1 km NW of Caleta La Arena, 23

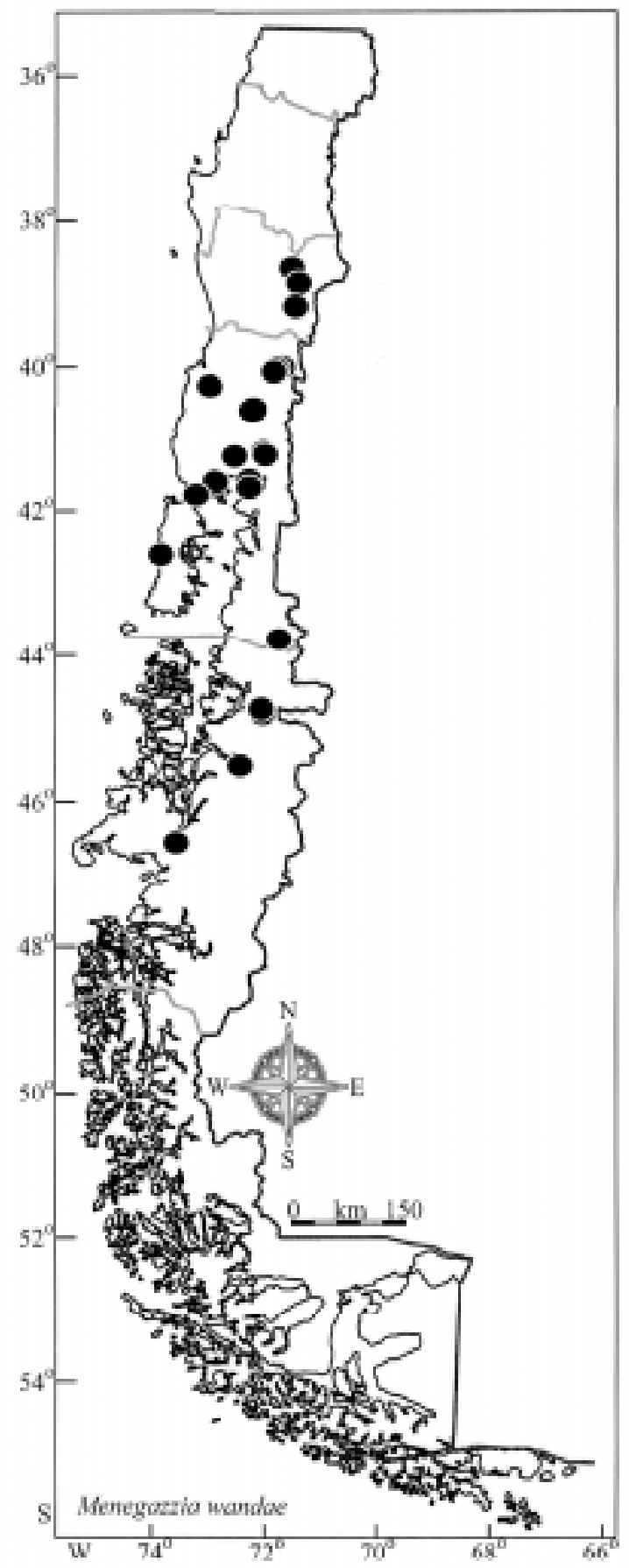

Fig. 10: Distribution of Menegazzia wandae in Chile.

Distribución de Menegazzia wandae en Chile. 
February 2001, J. W. Bjerke 777/01, 787/01 (UV), 811/01 (TROM); $40 \mathrm{~km} \mathrm{SW}$ of Puerto Montt, 3 $\mathrm{km}$ NE of Puente los Palos, 17 November 2000, A. Elvebakk 00:442 (TROM). Tenth Region of Chile, Province of Chiloé: Cucao, Parque Nacional de Chiloé, near Guardería, 18 November 2000, A. Elvebakk 00:537A (TROM). Tenth Region of Chile, Province of Palena: Carretera Austral, limit between regions Ten and Eleven, February 1985, W. Quilhot 1799 (UV). Eleventh Region of Chile, Province of Aisén: Río Cisnes, 18 February 1985 , W. Quilhot 1800 (UV); Lago Riesco, 22 November 1993, W. Quilhot 3065 (UV). Eleventh Region of Chile, Province of Capitán Prat: Parque Nacional Laguna San Rafael, November 1997, W. Quilhot 1523 (UV).

\section{Key to species}

1. Soralia derived from \pm inflated vesicles or in helmet-shaped extensions of the lobes; thallus yellow-green (usnic acid)..................................... M. globulifera

1. Soralia not vesicular in origin; thallus greyish (atranorin).

2. Soralia predominantly associated with perforations; stictic acid complex present.

2. Soralia not, or only in exceptional cases, associated with perforations; stictic acid complex present or absent. ... 3.

3. Soralia maniciform or derived from pustules, normally showing an open duct to the medullary cavity. . 4.

3. Soralia convex to subcapitate, only rarely with an open duct to the medullary cavity.

4. Soralia formed on 1-2 mm tall pustules; stictic acid complex absent. 7.

4. Soralia not raised substantially above the upper surface; stictic acid complex present or absent. .......................... 6 .

5. Lobes without black margins; pustules with a well-defined sorediate apex; fumarprotocetraric acid present.

5. Lobes with brown-black margins; pustules lacerate; thamnolic acid present. ... M. fumarprotocetrarica M. wandae

6. Soralia small; few soredia in each soralium; perforations mostly ellipsoid; apothecia not known; protolichesterinic and lichesterinic acids present. M. tenuis

6. Soralia variable; soredia numerous; perforations \pm circular; occasionally fertile; stictic acid complex present. .................................................................. magellanica

7. Upper side of internal cavity ochre-yellow and $\mathrm{UV}+$ pale orange. .......................................................... chrysogaster

7. Upper side of cavity white or brown-black and UV- or UV+ sky blue with or without orange patches. .... 8.

8. Lobes grey to salad-green on fresh material, emaculate, sympodially branched; soralia seldom confluent; soralia and medulla UV+ sky blue (hypothamnolic acid). M. sanguinascens

8. Lobes greyish, slightly to prominently maculate, subdichotomously to irregularly ramified.

Soralia UV- (stictic acid complex or norstictic acid)......................... 9.

9. Soralia small (0.2-0.6 mm wide), not confluent, occasionally in groups; often fertile; most common on shrubs. M. subpertusa
9. Soralia large (0.4-1.2 mm wide), often confluent; rarely fertile, mostly on branches and trunks of trees and shrubs.

10. Lobes only slightly maculate; soralia and medulla occasionally with orange patches (norstictic acid)...... norsorediata

11. Lobes maculate; soralia and medulla without orange patches (stictic acid complex)........................... M. kawesqarica

Literature reports from regions Four to Eleven and Islas Juan Fernández.

Several older reports of Menegazzia terebrata (as M. pertusa and Parmelia pertusa) from Chile exist (e.g., Hue 1892, Räsänen 1932: Las Trancas, Eighth Region). The presence in Chile of this mainly holarctic species was not accepted by Santesson (1942) or Bjerke \& Elvebakk (2001). Menegazzia terebrata s. str. in South America is known only as far south as southern Ecuador (Bjerke 2002). Santesson (1942) recorded $M$. sanguinascens from Islas Juan Fernández and from Las Trancas (Eighth Region of Chile). The specimen from Las Trancas was re-examined and redetermined as $M$. subpertusa (see under this species). The specimen from Islas Juan Fernández reported by Santesson (1942) is probably referable to $M$. neozelandica. Menegazzia sanguinascens was reported from trunks of Araucaria araucana in Lonquimay by Redon (1973). Menegazzia tenuis was recorded from Fray Jorge (Redon et al. 1975). The specimens collected by Redon and his colleagues in Fray Jorge proved to be M. neozelandica. Quilhot et al. (1975) recorded M. magellanica, M. globulifera, M. sanguinascens and $M$. tenuis from various localities in regions Nine to Eleven in a study dealing with the chemistry of Menegazzia. Most of their examined specimens are lost. However, one of the specimens reported as $M$. sanguinascens proved to be $M$. chrysogaster, whereas one specimen reported as $M$. magellanica proved to be $M$. wandae, and the other specimens reported as $M$. magellanica may also be referable to $M$. wandae. The specimen from Llanquihue reported as $M$. tenuis is probably referable to $M$. norsorediata since norstictic acid was detected. Redon \& Quilhot (1977) also recorded M. sanguinascens from Islas Juan Fernández. One of the specimens on which they based their record was seen and redetermined to $M$. neozelandica.

Menegazzia sanguinascens was reported to associate with Nephroma australe, Coccotrema cucurbitula and several other lichens in a rainforest locality at Puerto Manzano (Tenth Region of Chile) (White \& James 1988). Galloway (1992a) listed $M$. globulifera from Laguna San Rafael. Menegazzia magellanica and $M$. sanguinascens were listed as 
species associated with Pseudocyphellaria guzmanii and $P$. compar in Valdivian rainforest (Galloway 1992b). This report of M. magellanica is probably referable to $M$. wandae. Menegazzia neozelandica was reported from the Eleventh Region, and considered vulnerable and insufficiently known by Quilhot et al. (1998). Based on literature reports (see above), Elix \& McCarthy (1998) listed $M$. sanguinascens and $M$. terebrata from Islas Juan Fernández. In his treatment of important lichen habitats in Chile, Galloway (1998) reported that $M$. globulifera, $M$. magellanica and $M$. sanguinascens occur in Patagonian Nothofagus forest (regions Eight to Twelve of Chile). Bjerke (2001) described M. wandae and mapped six localities. Bjerke \& Elvebakk (2001) included a few records of $M$. chrysogaster, $M$. fumarprotocetrarica, M. kawesqarica, $M$. neozelandica and $M$. norsorediata from localities north of Twelfth Region. Quilhot et al. (2002a, 2002 b) reported the following sorediate species from Laguna San Rafael: M. chrysogaster, $M$. fumarprotocetrarica, $M$. globulifera, $M$. magellanica, M. neozelandica, M. norsorediata, $M$. sanguinascens, $M$. wandae. The presence of $M$. chrysogaster, $M$. magellanica and $M$. sanguinascens in Laguna San Rafael could not be confirmed here.

\section{Ecological requirements}

The affiliations of the sorediate species of Menegazzia to the temperate and antiboreal vegetation zones, as defined here, are outlined in Table 1. The temperate high-altitude mixed deciduous-coniferous forest and the antiboreal rainforest are the most species-rich vegetation zones, with eight affiliated species each. The high-altitude forest zone, which is located between 600 and $2,000 \mathrm{~m}$ from latitude $37^{\circ}$ to $44^{\circ} \mathrm{S}$, has several species in common with the antiboreal evergreen and deciduous forests in the southernmost part of Chile. Menegazzia tenuis has a remarkable disjunct distribution, with one known locality on $N$. dombeyi in a mixed A. araucana- $N$. dombeyi forest. Also M. kawesqarica is in Central southern Chile mostly restricted to higher altitudes within this vegetation zone. Several lichens from other genera that are common at low altitudes in the antiboreal region are confined to higher altitudes in the temperate region, e.g., Pseudocyphellaria freycinetii, $P$. lechleri, $P$. vaccina (Galloway 1992b), Protousnea magellanica, P. malacea (Krog 1976), Cladonia rangiferina, Cladonia borealis (Stenroos 1995), Bunodophoron australe, B. imshaugii, B. ramuliferum (Wedin 1995), Sticta gaudichaldia

TABLE 1

Vegetation zone affiliation of sorediate species of Menegazzia in Chile. See text for full names of vegetation zones

Afiliación de zonas de vegetación para las especies sorediosas de Menegazzia en Chile. Ver el texto para nombres completos de las zonas de vegetación

Vegetation zone

1. Tropical zones

2. Mediterranean zones

3. Temperate zones

3A. Warm-temperate forest

3B. Valdivian rainforest

3C. North-Patagonian rainforest

3D. High-altitude forest

3E. East-Patagonian steppe zones

4. Antiboreal zones

4A. Magellanic moorland

4B. Antiboreal rainforest

4C. Antiboreal deciduous forest

4D. Antiboreal heathland
Species

M. neozelandica, $M$. subpertusa

M. chrysogaster, $M$. neozelandica, M. norsorediata, M. sanguinascens,

M. subpertusa, $M$. wandae

M. chrysogaster, $M$. neozelandica, $M$. norsorediata, M. sanguinascens,

M. subpertusa, M. wandae

M. chrysogaster, $M$. fumarprotocetrarica, $M$. globulifera, $M$. kawesqarica, M. norsorediata, $M$. sanguinascens, $M$. subpertusa, $M$. tenuis

Insufficiently known; probably $M$. chrysogaster, $M$. neozelandica, $M$. norsorediata, $M$. sanguinascens, $M$. subpertusa, $M$. tenuis

M. chrysogaster, $M$. fumarprotocetrarica, . globulifera, M. magellanica,

$M$. neozelandica, $M$. norsorediata, $M$. sanguinascens, $M$. tenuis

M. globulifera, M. kawesqarica, M. magellanica

M. globulifera, M. kawesqarica, M. magellanica 
(Galloway 1994), and Nephroma analogicum (White \& James 1988). The temperate, high-altitude forests along the Chilean-Argentinean border appear, at least to some degree, to be a climatic equivalent to the antiboreal forests at lower altitudes south of latitude $48^{\circ} \mathrm{S}$. Adopting the terminology advocated by Ahti et al. (1968) and Tuhkanen (1992), these high-altitude forests could be called 'oroantiboreal'.

The Valdivian and North-Patagonian rainforest zones share the same sorediate species of Menegazzia (Table 1). Within other lichen genera, some Valdivian rainforest lichens are rare or lacking in North-Patagonian forests, e.g., Pseudocyphellaria norvegica, $P$. exanthematica (Galloway 1992b), Bunodophoron dodgei and B. whakapapaense (Wedin 1995), but most 'Valdivian rainforest lichens' are common also in North-Patagonian cool-temperate forests, and some are even distributed as far south as the Magellanic moorland. Thus, the boundary between the Valdivian and North-Patagonian rainforests does not appear to be an important boundary for lichen distribution.

The studied species show a variety of adaptations to humidity and temperatures. The driest vegetation zones, such as the warm temperate forest, the East-Patagonian steppes, and the antiboreal heathland, have few Menegazzia species (Table 1). A diagrammatic presentation of the species' ecological requirements is shown in Fig. 11. Menegazzia wandae and M. neozelandica show clear preferences for the most humid lowland areas. Menegazzia fumarprotocetrarica and M. sanguinascens prefer slightly less humid habitats than the two former species. Menegazzia norsorediata, M. subpertusa and M. globulifera grow in habitats with intermediate to low humidity, and accept a high temperature range. Menegazzia chrysogaster tolerates many combinations of temperature and humidity. In the southern part, it shows a tendency towards drier microhabitats, at least in Tamango. Menegazzia tenuis is a specialist of shaded habitats with high humidity in areas with low temperatures. Menegazzia magellanica and M. kawesqarica prefer cool habitats with intermediate to low humidity.

Several of the sorediate species of Menegazzia grow as pioneers in their respective habitats. In particular, M. neozelandica, M. norsorediata and M. subpertusa are early colonisers of newly developed substrates (young twigs of shrubs and trees). In the same habitats, remarkably few thalli of fertile species of Menegazzia were observed. Thus, asexual reproduction by soredia seems to favour rapid establishment, whereas reproduction by spores requires more time to develop visible thalli.
To conclude, 11 sorediate species of Menegazzia are known from Chile. Menegazzia subpertusa is reported as new to Chile. Three of the species, $M$. kawesqarica, M. tenuis and M. magellanica show the strongest preferences for antiboreal vegetation zones. One species, M. wandae, is mostly confined to temperate rainforest and has the most restricted latitudinal distribution range. Menegazzia neozelandica is particularly common in coastal, humid areas, and is the only species of Menegazzia that is known from Islas Juan Fernández and in Fray Jorge. Menegazzia fumarprotocetrarica is a rare species in Chile, but is more common in high-altitude forest in Ninth Region than in any other area of the country. The remaining species, $M$. sanguinascens, $M$. chrysogaster, $M$. norsorediata, M. globulifera and $M$. subpertusa have a wide distribution range. The two first are most common in habitats of intermediate shade, whereas the three latter species protrude into the drier forest habitats.

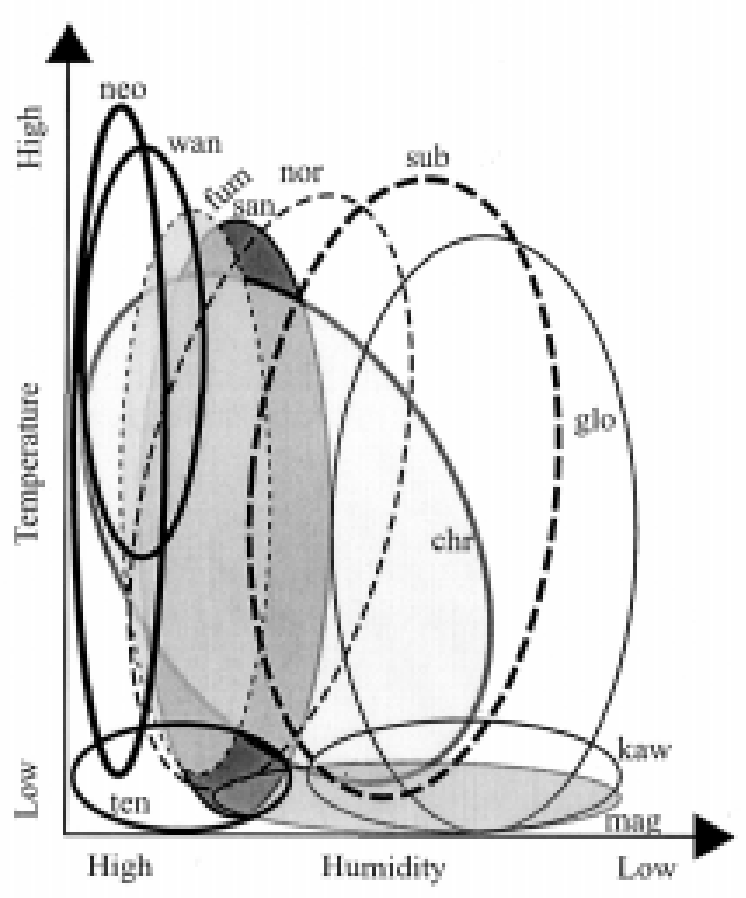

Fig. 11: Graphical depiction of the ecological preferences of the sorediate species of Menegazzia in southern South America. The scales show relative values. The species names are abbreviated (three first letters in species epithet).

Presentación gráfica de las preferencias ecológicas de las especies sorediosas de Menegazzia en el parte austral de América del Sur. Se presentan las escalas en valores relativos. Nombres ciéntificos son abreviados (las tres primeras letras del epíteto). 


\section{ACKNOWLEDGEMENTS}

We thank Corporación Nacional Forestal (CONAF) for permission to collect lichens in Chilean national parks. We are grateful to curators of B, BG, GZU, H, HIP, HO, MSC, O, S and UPS for loan of specimens, and to Cecilia Rubio, Universidad de Valparaíso, for assistance with TLC analyses.

\section{LITERATURE CITED}

ADLER M \& S CALVELO (1996) Two new species of the genus Menegazzia (Parmeliaceae sensu lato, lichenized Ascomycotina) from southern South America. Mycotaxon 59: 367-372.

AHTI T, L HÄMET-AHTI \& J JALAS (1968) Vegetation zones and their sections in northwestern Europe. Annales Botanici Fennici 5: 169-211.

AMIGO J \& C RAMÍREZ (1998) A bioclimatic classification of Chile: woodland communities in the temperate zone. Plant Ecology 136: 9-26.

ARROYO MTK, JJ ARMESTO, F SQUEO \& J GUTIÉRREZ (1993) Global change: flora and vegetation of Chile. In: Mooney H, EK Fuentes \& BI Kronberg (eds) Earth system responses to global change: contrasts between North and South America: 239-263. Academic Press Inc., San Diego, California.

BELTMAN HA (1978) Vegetative Strukturen der Parmeliaceae und ihre Entwiklung. Bibliotheca Lichenologica 11: 1-193.

BERNASCONI E, S CALVELO \& MT ADLER (2002) Menegazzia (Parmeliaceae: Ascomycota) and an associated lichenicolous fungus, Abrothallus parmeliarum, from Patagonia, Argentina. Australian Systematic Botany 15: 527-534.

BJERKE JW (2001) A new sorediate species of Menegazzia (Parmeliaceae, lichenized Ascomycota) from Chile. Lichenologist 33: 117-120.

BJERKE JW (2002) A new fertile species of Menegazzia and notes on two sorediate species from the Neotropics. Lichenologist 34: 503-508.

BJERKE JW \& A ELVEBAKK (2001) The sorediate species of the genus Menegazzia (Parmeliaceae, lichenized Ascomycotina) in southernmost South America. Mycotaxon 78: 363-392.

CALVELO S \& M ADLER (1994) Menegazzia (Ascomycotina, liquenizado) en la Argentina. Boletín de la Sociedad Argentina de Botánica 30: 119-125.

CULBERSON CF (1972) Improved conditions and new data for the identification of lichen products by a standardized thin layer chromatographic method. Journal of Chromatography 72: 113-125.

DONOSO CZ (1995) Bosques templados de Chile y Argentina. Editorial Universitaria, Santiago, Chile. 484 pp.

ELIX JA \& PM McCARTHY (1998) Catalogue of the lichens of the smaller Pacific Islands. Bibliotheca Lichenologica 70: 1-361.
ELVEBAKK A \& R MOBERG (2002) Foliose and placodioid species of the lichen family Physciaceae in southernmost Chile. Lichenologist 34: 311-320.

FILSON RB (1996) Checklist of Australian Lichens and Allied Fungi. Flora of Australia Supplementary Series 7, Australian Biological Resources Study, Canberra, Australia. 205 pp.

GALLOWAY DJ (1985) Flora of New Zealand lichens. P.D. Hasselberg, N. Z. Government GALLOWAY DJ (1992a) Lichens of Laguna San Rafael, Parque Nacional 'Laguna San Rafael', southern Chile: indicators of environmental change. Global Ecology and Biogeography Letters 2: 37-45.

GALlOWAY DJ (1992b) Studies in Pseudocyphellaria (lichens) III. The South American species. Bibliotheca Lichenologica 46: 1-275 + 44 figures.

GALLOWAY DJ (1994) Studies on the lichen genus Sticta (Schreber) Ach.: I. Southern South American species. Lichenologist 26: 223-282.

GALLOWAY DJ (1998) The lichens of Chile: present knowledge and future prospects. In: Marcelli MP \& MRD Seaward (eds) Lichenology in Latin America: history, current knowledge and applications: 87-100. Companhia de Tecnologia de Saneamento Ambiental, São Paulo, Brasil.

GALLOWAY DJ \& W QUILHOT (1999 “1998”) Checklist of Chilean lichen-forming and lichenicolous fungi. Gayana Botánica (Chile) 55: 111-185.

GRAU J (1992) Clima y distribución geográfica de la Flora de Chile. In: Grau J \& G Zizka (eds) Flora silvestre de Chile: 11-24. Sonderheft 19, Palmengarten, Frankfurt Am Main, Germany.

GRAU J (1995) Aspectos geográficos de la flora de Chile. In: Maticorena C \& R Rodríguez (eds) Flora de Chile, Volume 1, Pteridophyta-Gymnospermae: 63-83. Ediciones de la Universidad de Concepción, Concepción, Chile.

HUE AM (1892) Lichenes exoticos a professore W. Nylander descriptos vel recognitos et in herbario musei Parisiense pro maxima parte asservatos in ordine systematico disposuit (continuatio). Nouvelles Archives du Muséum d'Histoire Naturelle de Paris 3, 4: 103-210.

JAMES PW \& DJ GALLOWAY (1992) Menegazzia. Flora of Australia 54: 213-246.

KANTVILAS G \& SJ JARMAN (1999) Lichens of rainforest in Tasmania and south-eastern Australia. Flora of Australia Supplementary Series 9, Australian Biological Resources Study, Canberra, Australia. $x i+212$ pp.

KROG H (1976) Lethariella and Protousnea, two new lichen genera in Parmeliaceae. Norwegian Journal of Botany 23: 83-106.

MARTICORENA C \& M QUEZADA (1986) Catálogo de la flora vascular de Chile. Gayana Botánica (Chile) 42: 1-157.

QUILHOT W, J REDÓN \& E ZÚÑIGA (1975) Estudios fitoquímicos en el género Menegazzia Mass. emend. Sant. (Parmeliaceae). Anales del Museo de Historia Natural de Valparaíso (Chile) 8: 108-113.

QUILHOT W, I PEREIRA, G GUZMÁN, R RODRÍGUEZ, I SEREY, E BARRERA, V MALDONADO \& $\mathrm{R}$ MELÉNDEZ (1998) Categorías de conservación de líquenes nativos de Chile. Boletín del Museo Nacional de Historia Natural (Chile) 47: 9-22. 
QUILHOT W, C RUBIO, M BERNAL \& M WEDIN (2002a) Estructura de comunidades liquénicas en Embothrium coccineum (Proteaceae) en Laguna San Rafael, Chile. Boletín del Museo Nacional de Historia Natural (Chile) 51: 85-96.

QUILHOT W, C RUBIO \& JW BJERKE (2002b) El género Menegazzia (Parmeliaceae, Ascomyotina liquenizado) en Laguna San Rafael, Aisén, Chile. Boletín del Museo Nacional de Historia Natural (Chile) 51: 81-84.

RÄSÄNEN V (1932) Zur Kenntnis der Flechtenflora Feuerlands sowie der Prov. de Magallanes, Prov. de Chiloë und Prov. de Nuble in Chile. Annales Botanici Societatis Zoologicae Botanicae Fennicae Vanamo 2, 1: I-VI + 1-68.

REDÓN J (1973) Beobachtungen zur Geographie und Ökologie der Chilenischen Flechtenflora. Journal of the Hattori Botanical Laboratory 37: 153-167.

REDóN J, W QUILHOT \& E ZÚÑIGA (1975) Observaciones sistemáticas y ecológicas en líquenes del Parque Nacional Fray Jorge. Anales del Museo de Historia Natural de Valparaíso (Chile) 8: 51-57.

REDÓN J \& W QUILHOT (1977) Los líquenes de Juan Fernández. I. Estudio preliminar. Anales del Museo de Historia Natural de Valparaíso (Chile) 10: 15-26.

SANTESSON R (1942) The South American Menegazziae. Arkiv för Botanik 30A, 11: 1-35.
SCHMITHÜSEN J (1956) Die räumliche Ordnung der chilenische Vegetation. Bonner Geographische Abhandlungen 17: 1-89.

SCHMITT I, MI MESSUTI, GB FEIGE \& HT LUMBSCH (2001) Molecular data support rejection of the generic concept in the Coccotremataceae (Ascomycota). Lichenologist 33: 315-321.

STENROOS S (1995) Cladoniaceae (Lecanorales, lichenized Ascomycotina) in the flora of Chile. Gayana Botánica (Chile) 52: 89-131.

TUHKANEN S (1992) The climate of Tierra del Fuego from a vegetation geographical point of view and its ecoclimatic counterparts elsewhere. Acta Botanica Fennica 145: 1-64.

WEDIN M (1995) The lichen family Sphaerophoraceae (Caliciales, Ascomyotina) in temperate areas of the Southern Hemisphere. Symbolae Botanicae Upsaliensis 31, 1: 1-102.

WHITE FJ \& PW JAMES (1985) A new guide to microchemical techniques for the identification of lichen substances. British Lichen Society Bulletin 57 (supplement): 1-41.

WHITE FJ \& PW JAMES (1988) Studies on the genus Nephroma II. The southern temperate species. Lichenologist 20: 103-166. 